\title{
Szegénység, projektek, közpolitikák
}

\section{Poverty, projects, public policies}

\author{
VÁRADI MONIKA MÁRIA
}

VÁRADI Monika Mária: tudományos főmunkatárs, MTA Közgazdaság-és Regionális Tudományi Kutatóközpont, Regionális Kutatások Intézete, Budapest; varadim@rkk.hu

KULCSSZAVAK: szegénység, társadalmi kirekesztettség, a szegénység mérséklését szolgáló projektek, jóléti politika, közfoglalkoztatás

ABSZTRAKT: Az utóbbi években hazai és nemzetközi kutatások, jelentések sora hívja fel a figyelmet a mélyülő szegénységre, erősödő társadalmi és területi polarizációra Magyarországon. Kétségtelen, hogy e kedvezőtlen tendenciákban a válság hatásai is tetten érhetők, tanulmányomban mégis amellett kívánok érvelni, hogy az állam által végrehajtott ,jóléti fordulat" perdöntő szerepet játszik a szegénységet, kirekesztettséget, egyenlőtlenségeket tápláló struktúrák, folyamatok tartósságában, fennmaradásában. Uniós tagállamként Magyarország is célul tüzte ki a szegénység és kirekesztettség mérséklését szolgáló politikák céljainak, eszközeinek átvételét, gyakorlatba ültetését. A 2013 tavaszán és nyarán tizenegy kistérségben végzett empirikus kutatásunk alapvető kérdése az volt, hogy vajon a szegénység mérséklését szolgáló, elsősorban uniós forrásokból megvalósuló projektek, programok alkalmasak-e arra, s ha igen, milyen mértékben, milyen feltételek mellett, hogy mérsékeljék a szegénység, a társadalmi kirekesztettség újratermelődésének esélyét. A szegénységet fenntartó struktúrák és folyamatok azonosítása mellett e projektek értékelésére is megkértük interjúpartnereinket. A vizsgált vidéki térségekben általános és más kutatási tapasztalatokkal egybecsengő meggyőződés, hogy a generációkon átívelően újratermelődő szegénység olyan összetett problémahalmazt jelent, amely egy-egy projekt időtartama alatt és projektszemlélettel nem oldható meg. A kedvezőtlen tendenciák megfordításához a projektek és az intézményi struktúrák, tágabban a szegénységben élők helyzetét, perspektíváit meghatározó közpolitikák céljainak, eszközrendszerének összhangja elengedhetetlen. E tekintetben Magyarországon súlyos deficitekről beszélhetünk. Az elmúlt évek közpolitikai változásai a szegénység mérséklését szolgáló projektek, programok célkitüzéseinek ellenében a szegénység és kirekesztettség mélyüléséhez vezetnek. Mivel a kormányzat a szegénység mérséklésének és kezelésének jószerivel kizárólagos eszközévé a közfoglalkoztatást tette, tanulmányunkban e program elemzésére fókuszálunk, bemutatva piactorzító, és a szegénységben élőket a munkanélküliség csapdájában, tartós függőségben, kiszolgáltatottságban tartó hatásait.

Monika Mária VÁRADI: senior research fellow, Institute for Regional Studies, Centre for Economic and Regional Studies, Hungarian Academy of Sciences, Budapest; varadim@rkk.hu

KEYWORDS: poverty, social exclusion, projects targeting alleviation of poverty and exclusion, welfare policies, public works programmes

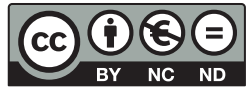


ABSTRACT: This study presents some results of a qualitative research carried out in eleven different rural areas of Hungary. The topic of the research was how and to what extent different projects targeted at the alleviation of Roma and non-Roma poverty and social exclusion meet their objectives. The most important projects implemented in the disadvantaged areas and communities under study have been financed by the European Union.

We can easily identify the interrelated, mutually enhancing factors sustaining poverty: long-term unemployment, low education, low and uncertain incomes of families. Deep poverty, especially child poverty, concentrates in disadvantaged, peripheral areas, thus social and territorial exclusion correlate.

There are some lessons which can be drawn from the local experience of implementing projects aiming at alleviating poverty. The main question is, whether the positive changes, results and effects induced by the projects in question can be sustained after their closure. There is a broad consensus that the complex problem of deep-rooted self-reproducing poverty cannot be solved within the framework of short-time projects. It is not only about the frequent lack of synergy of different projects and programmes, but rather about the relationship between projects and public policies which explicitly or implicitly influence poverty and the poor, strengthening or even weakening the institutions and structures of social inclusion in the society.

In the rural areas under study, the general experience our interviewees shared with us has been the growing risk of poverty and exclusion, the deepening of poverty, trends fuelling exclusionary discourses about the (Roma) poor, weakening solidarity and the decreasing integrating force of local societies. Local experience is in accordance with recent European reports which highlight the worsening position of Hungary regarding poverty, social exclusion and social justice. These trends can also be interpreted as the negative impact of the crisis. Not questioning the relevance of that interpretation, we argue in this study, in accordance with other recent researches, that it has been the exclusionary social policy reforms which themselves contribute to the deepening of poverty and social exclusion in the Hungarian society. To provide only a few examples, the new constitution reduced the right for social security, and the government has cut the length and the level of unemployment benefits, the amount of social assistance and the public workers' wages radically. The new unemployment benefit system curbed the social right of the unemployed and replaced activation policies with a compulsory public works programme.

The public works programme is applied by the government as the virtually universal means of combating unemployment and poverty. However, empirical research highlights that it barely meets its objectives. The programme does not provide (re)entry into the first labour market; in addition, it significantly weakens the ties of the public workers to the world of the informal labour market. The amount of wages offered for public work is higher than that of the social welfare, and can temporarily increase the incomes of poor families, but it is not enough to help them out of poverty. Beyond that, the public works programme strengthens the dependency of the poor on the local authorities. The public works programme does not offer a way out for the poor, but is not more than a trap.

\section{Bevezetés}

Növekvő, mélyülő egyenlőtlenségek és szegénység - az utóbbi évek meghatározó tendenciája Európa-szerte és Magyarországon. A társadalmi igazságosság ${ }^{1}$ európai helyzetéről tájékoztató Bertelsmann-jelentés szerint a válság eredményeként az Európai Unió országaiban egyre többeknek kell szembesülniük a szegénység kockázatával, az emberek negyedét sújtja a szegénység és a társadalmi kirekesztés, ami különösen súlyosan érinti a fiatal és gyermekkorú nem- 
zedékeket. Az aggasztó folyamat azonban nem egyforma mélységben érinti az uniós tagállamokat; az utóbbi években növekedett a megosztottság a fejlett északi és a déli, tartós válsággal küzdő országok között. Magyarország ez utóbbi országok (Olaszország, Románia, Bulgária, Görögország) társaságában osztozva a sereghajtók közé tartozik a társadalmi igazságosság mértékét jelző dimenziókat tekintve. ${ }^{2}$ A kedvezőtlen pozíció megítélését tovább árnyalja, hogy a számítások a 2008 és 2011 közötti időszakban romló helyzetről tanúskodnak (Schraad-Tischler, Kroll 2014). Az európai összehasonlító tanulmányok (lásd még Eurostat 2013) és a hazai elemzések eredményei egybecsengenek. Az ezredforduló óta eltelt bő évtized alatt a szegénység nemcsak kiterjedt és egyre többeket érint, de mélyült is; a szegénységben élők egyre távolabb kerültek annak az esélyétől, hogy helyzetükből valaha is kilábaljanak (Gábos, Szívós, Tátrai 2013). A magyar társadalomban 2009 és 2012 között nem csupán a jövedelmi különbségek növekedtek, de erősödött a társadalmi polarizáció, és az utóbbi években jelentős mértékben romlott a gyermeket nevelő családok helyzete, növekedett a gyermekszegénység (Civil jelentés 2014).

A társadalmi polarizáció egyben térbeli is. A szegénység és társadalmi kirekesztettség területi összefüggésére az uniós szintü összehasonlító adatok is rámutatnak. A szegénység és kirekesztettség kockázatával a vidéken élők minden uniós országban nagyobb eséllyel szembesülnek, mint a városias terek lakói, ${ }^{3}$ a rurális szegénység kockázata azonban az átlagosnál is nagyobb az unióhoz 2004-ben és 2007-ben csatlakozott államokban, köztük Magyarországon (Eurostat 2013, 226-235.). Különböző hazai kutatások szerint Magyarországon a rendszerváltás óta eltelt időszakban növekedtek a területi egyenlőtlenségek. A dinamikusan fejlődő központokhoz közel fekvő, lakóiknak megfelelő munka- és jövedelemszerzési esélyeket kínáló kistérségek, valamint az ország krízisövezeteiben elhelyezkedő kistérségek közötti különbségek egyre nagyobbak, a tartós gazdasági és társadalmi válsággal sújtott, észak-magyarországi és dél-dunántúli szegregált, vagy szegregálódó vidéki terek helyzete folyamatosan romlik, a szegénység, különösen a gyermekszegénység koncentráltan jelenik meg e vidékeken (Bihari, Kovács 2004; Civil jelentés 2014; Kovács 2013; Koós 2015).

A vázolt kedvezőtlen folyamatok, az országon belül erősödő társadalmi és térbeli polarizáció, a szegénység terjedése és mélyülése nyilvánvalóan összefügg a gazdasági válsággal (Szikra 2014). Ugyanakkor az Európai Unió tagjaként Magyarország is hitet tett és kötelezettséget vállalt a szegénység és a társadalmi kirekesztés elleni politika megvalósítása mellett (lásd Civil jelentés 2014; Váradi 2004). Ennek megfelelően az elmúlt években uniós támogatású projektek sorát valósították meg, amelyek célja a szegénység mérséklése, elsősorban a mélyszegénységben élők helyzetének javítása volt.

A 2013 tavaszán és nyarán tizenegy kistérségben végzett empirikus kutatásunk $^{4}$ alapvető kérdése az volt, hogy vajon a szegénység mérséklését szolgáló, elsősorban uniós, de hazai forrásokból is megvalósuló projektek, programok alkalmasak-e arra, s ha igen, milyen mértékben, milyen feltételek mellett, hogy mérsékeljék a szegénység, a társadalmi kirekesztettség újratermelődésének esélyét. 
A kiválasztott kutatási terepeken strukturált interjúkat készítettünk településvezetőkkel, a különböző projekteket, programokat megvalósító szakemberekkel, menedzserekkel, s a projektekben résztvevő munkanélküli, szegénységben élő emberekkel. A terepmunka eredményeit a közreműködő kutatók esettanulmányokban foglalták össze, tanulmányunk alapvetően az ezekből leszürhető tapasztalatokra, tanulságokra, valamint más, tárgyunkat érintő kutatásokra támaszkodik.

\section{A szegénységet tápláló és fenntartó folyamatok, struktúrák}

A szegénység ${ }^{5}$ okairól gondolkodva interjúpartnereink mindenekelőtt a munkanélküliséget, az elsődleges munkaerőpiacon elérhető munkahelyek hiányát, szükösségét említették. A helyi tapasztalatok megerősítik az ismert összefüggéseket. A piacgazdaságra áttérő Magyarországon a tömeges munkanélküliséggel együtt megjelent az „új szegénység” (Andorka, Spéder 1996; Spéder 2002), nyilvánvalóvá vált, hogy a legnagyobb szegénységi kockázatot az elsődleges munkaerőpiacról való tartós kiszorulás, a szervezett munka világához való gyenge kötődés jelenti. Nem véletlen, hogy a szegénység, valamint a társadalmi kirekesztés mérséklését célzó uniós stratégia centrumában a nyitott, befogadó munkaerőpiac kialakítása, a foglalkoztatás bővítése áll (Krémer 2003). Másként fogalmazva: a társadalmi befogadásnak alapvető feltétele a munkaerőpiacon, a munka világában való jelenlét (lásd például Castel 1993, 1998, 2005; Ferge 2000; Ferge, Tausz, Darvas 2002; Spéder 2000, Szalai 2002). ${ }^{6}$ A mai Magyarországon egymillió ember él a munkaerőpiac peremén: azok, akiknek ha van is állása, az rosszul fizetett és bizonytalan; akik csak idénymunkából tudnak megélni; akik ellátásban részesülő vagy ellátatlan munkanélküliek; akik közülük éppen közfoglalkoztatásba kerültek; akik fiatalként vagy gyermekgondozás után nem tudnak elhelyezkedni (A munkaerőpiac peremén 2014). Vagyis mindazok a peremen találhatók, akik az elsődleges munkaerőpiachoz nem vagy csak nagyon gyenge szálakkal kötődnek. A hiányzó vagy gyenge munkaerő-piaci kötődés a vizsgált vidéki térségekben is a tartós szegénység legfontosabb strukturális oka.

A szegénység fennmaradásában, újratermelődésének folyamatában egymással szétbogozhatatlanul összefonódó tényezők játszanak szerepet. A kutatás terepeiként szolgáló vidéki terek többségében az összeomlott gazdasági, foglalkoztatási kapacitások negyedszázada nem, vagy csak hiányosan, egyoldalúan épültek újra, ahogy az is jellemző, főként az aprófalvas szerkezetü vidékeken, hogy a közeli centrumok gazdasága sem regenerálódott olyan mértékben, hogy dinamizálni tudná stagnáló vagy romló helyzetű környéküket. A kutatás során hallhattunk történeteket megszűnt üzemekről, arról, hogy a válság még sebezhetőbbé tette a munkaerőpiacot. Példaként az Elcoteq szolgálhat. Az 1998-ban Pécsen megtelepedett multinacionális elektronikai tömeggyártó üzem a dél-dunántúli régió 
legjelentősebb foglalkoztatójává vált, amely a munka betanított jellegének és a vállalat „színvak” személyzeti politikájának köszönhetően jelentős - bár a termelés ingadozásaihoz igazodó - számban foglalkoztatott képzetlen munkanélkülieket, köztük romákat is (Vidra 2013). A Sásdi kistérség több településéről is hozták-vitték a dolgozókat a vállalat munkásszállító buszai, így a cég 2011 őszén bekövetkezett csődje, majd bezárása érzékenyen érintette az itt élőket is, akik az elbocsátások után többnyire munkanélküliek lettek. Az Elcoteq buszai is csak a főútvonalakra fölfüződő településekre tértek be; a periferikus fekvésü, aprófalvas szerkezetű térségekben élők alapvető és tartós gondja a közeli vagy távolabbi centrumokban esetleg létező munkahelyek megközelíthetetlensége (Köllő 2006). A munkaadók nem szívesen alkalmaznak aprófalvakban élőket - „ha meghallják, hol lakom, lerakják a telefont" -, akiknek közlekedését nem akarják támogatni. A tapasztalatok szerint ha a tömegközlekedés egyáltalán igazodik is a müszakokhoz - s erről nem hallottunk pozitív példákat -, nem éri meg feltétlenül az elhelyezkedés, hiszen jellemzően minimálbérből kell az utazást és a munkavállalással járó egyéb költségeket fedezni.

Az alacsony iskolai végzettség is szegénységi kockázatot jelent, a foglalkoztatás alacsony szintjének egyik fontos okaként szakértők és helybeli beszélgetőtársaink is okkal azonosítják a (tartós) munkanélküliek alacsony iskolai végzettségét, elsődleges munkaerőpiacon értéktelen szaktudását. A kudarcos iskolai utak korrekcióját, az iskolarendszerben meg nem szerzett tudás, képességek, kompetenciák átadását, s egyben a munkanélküliek elsődleges munkaerőpiacra való be- és visszakerülését szolgálják a különböző, egy-egy projekthez, programhoz illeszkedő képzések is. E szakmai képzések az esetek meghatározó többségében nem nyújtanak valódi esélyt a munkaerő-piaci (re)integrációra, gyakran csak a közfoglalkoztatásban kamatoztathatók (lásd a parkgondozó, kisgépkezelő tanfolyamokat). A munkanélküliek számára a tanulmányi idő alatt folyósított támogatás teszi vonzóvá a képzéseket; egy dunántúli aprófaluban élő roma asszony kijelentette, hogy kizárólag a pénz miatt végzett el több tanfolyamot, még vagyonőri végzettsége is van, noha pontosan tudta, hogy elhelyezkedni soha nem tud a papírjaival. Terepmunka során gyakran találkoztunk „túlképzett" munkanélküliekkel, akik egyik megszerzett OKJ-s szakmával (pl. eladó, számítógép-kezelő, takarítónő, személy- és vagyonőr, kisgépkezelő) sem tudtak elhelyezkedni az elsődleges munkaerőpiacon.

A szegénységben élő, tartósan munkanélküli családok, háztartások megélhetésükben generációk óta szociális transzferekból, időszakos, informális vagy fekete munkavégzésből, valamint közfoglalkoztatásból származó jövedelmekre támaszkodhatnak. E megélhetési, pontosabban kényszerhelyzetben létrejött túlélési stratégiákat a változó lehetőségekhez való alkalmazkodás, rugalmasság jellemzi (Kotics 2013); a családok igyekeznek megragadni a mindig éppen kedvezőbbnek tűnő, jellemzően informális munka- és jövedelemszerzési alkalmakat. A mezögazdasági napszám, az erdőn végzett munka, a romák körében a gyógynövények, bodza, gomba stb. gyüjtése, a vasazás, a lomizás vagy tollgyüjtés máig 
elterjedt megélhetési, jövedelemszerzési, bevételnövelő stratégia. Ugyanakkor arról is hallottunk panaszt, hogy a lomizásnak, az erdőkben, útszéleken való gyűjtögetésnek ma már gátat szab a szabályozás; csak a tulajdonos hozzájárulásával lehet gombát, bodzát, diót stb. szedni. Ha rajtakapják az embert, büntetésre számíthat. A hagyományos megélhetési módok kriminalizálásának eredményét egy roma férfi így fogalmazta meg: „mindenki tilosban jár”. Majd' mindenütt azt hallottuk, hogy a mező- és erdőgazdaságban, építőiparban kínálkozó szezonális munkalehetőségek visszaszorultak az elmúlt években (lásd erről Hamar 2010; Simonyi 2010; Vida, Virág 2010), néhány alföldi településen pedig a Romániából és Ukrajnából érkező munkások kiszorították a helyi roma és nem roma szegényeket a munkaerőpiac e szegmenséből. A helyben kínálkozó informális munkalehetőségek, legyen szó a gazdák birtokán végzett rendszeres napszámról vagy az idősek portáján végzett kisebb-nagyobb munkákról, hagyományosan a kliens-patrónus viszony mentén alakultak. Ez a felek aszimmetrikus kapcsolatán alapuló, ám kölcsönös előnyükre váló és biztonságot jelentő viszony eltűnt vagy visszaszorulóban van, ami alapvetően a helyi társadalmak átalakulásából, etnikai szerkezetének megbillenéséből, a szegénység mélyüléséből fakad.

A munkahelyek hiánya, a megélhetési nehézségek sokakat késztetnek külföldi munkavállalásra. Ez a boldogulási stratégia minden kutatási terepünkön, romák (Autonómia 2013; Lukács 2013; Vidra, Virág 2013) és nem romák között egyaránt terjedőben van. Az osztrák-magyar határhoz közel fekvő zalai településeken nagy múltra tekint vissza a határ túloldalán való munkavállalás. Az egyik alföldi faluból asszonyok járnak rendszeresen idősgondozásra Németországba, Ausztriába, s hogy a munkavállalásukat megkönnyítsék, a községben német nyelvtanfolyamot szerveznek számukra. A baranyai településeken is több példát hallottunk a külföldi munkavállalásról; egy ötvenes éveiben járó roma önkormányzati vezető Spanyolországban dolgozik bányászként, több roma férfi németországi húsfeldolgozó üzemekben talált munkát, talán ennek is köszönhető, hogy az iskoláskorú roma fiúk körében a hentes szakma igen népszerű. Az ma még nem látható pontosan, hogy a külföldre irányuló munkavállalási célú migráció milyen következményekkel jár a helyi társadalmakban. A külföldön dolgozók által hazahozott/küldött jövedelem mérsékelheti a családok szegénységét: fizethető belőle a törlesztőrészlet, fedezhető a családi ház berendezése, felújítása, a gyerekek középiskolai tanulmányainak költsége, települési szinten is csökken a segélyekre, támogatásra szoruló családok száma. A tapasztalatok e migrációs folyamat szelektív természetére utalnak, azt mutatják, hogy a külföldi munkavállalás a fiatalabb, képzettebb, mobilabb emberek számára jelent alternatívát, a munkanélküliek között is jellemzően a szakmával rendelkező, illetve a helyzetük jobbra fordítása érdekében kockázatokat és áldozatokat vállaló asszonyok és férfiak választják ezt a lehetőséget. A külföldi munkavállalás jelentős indulótőkét (utazási és szállásköltségek) igényel, amelyet gyakran csak a tartalékok mozgósításával, néha személyes kölcsönnel teremtenek elő a családok. A legszegényebb, tartós társadalmi, térbeli kirekesztéssel, annak fizi- 
kai, lelki, életvitelbeli következményeivel sújtott családok inkább immobilak, nekik nincsenek mobilizálható tartalékaik, legfeljebb uzsorakölcsönért folyamodhatnak. Nem egy példa van arra is, hogy a külföldön munkát vállaló fiatalok ott is telepednek le és már csak látogatóba térnek haza. Mindez a kutatásba bevont települések túlnyomó többségében az évtizedek óta zajló demográfiai tendenciákat és kedvezőtlen következményeiket mélyíti el.

A népesség töretlennek nevezhetö fogyása maga is a szegénységet tápláló, fenntartó folyamat. A fiatal, mobilizálható - anyagi, kulturális tőkével rendelkező emberek elköltözése a helyi társadalmak elöregedését, az egyszemélyes idős háztartások növekvő számát, az időskorhoz köthető szegénység mélyülését eredményezi. A megbillent demográfiai és társadalmi szerkezet nem csak a helyi erőforrások elveszítésével (pl. oktatási intézmények bezárása) járhat. A szelektív elvándorlás a gettósodás kiteljesedéséhez, a mélyszegénységben élő roma népesség településen belüli arányának növekedéséhez vezet, de ott is a szegénység mélyülését eredményezi, ahol nem, vagy minimális számban élnek romák. Szabályt erősíto kivételek is akadnak. Néhány szatmári településen (Túristvándi, Rozsály) a bő két évtizede folyó helyi gazdaságfejlesztési programoknak, másutt (a Pest megyei tanyás községben, Nyársapáton) a jövedelmező kertészeti kultúrának köszönhetően, ha visszafordítani nem is, de mérsékelni sikerül a fiatalok elvándorlását.

A szociális migráció jelenségével több kutatási terepünkön is találkoztunk; szegények vagy elszegényedéssel fenyegetett családok kerekednek fel, hogy másutt találjanak olcsóbb lakhatást, könnyebb megélhetést, menedéket. Nem csak önként indulnak útnak, van, amikor egy városi önkormányzat úgy kíván megszabadulni a problémásnak tartott roma családoktól, hogy egy távoli, szegény, gettósodó faluban vásárol számukra ingatlanokat. Jártunk olyan alföldi községben is, ahol a helyi társadalomban éppen a beköltöző roma családoknak köszönhetően jelent meg a korábban ismeretlen mélyszegénység. Ez a szociális migráció nemcsak a helyi ellátórendszert állítja kihívások elé, de igen erős feszültségeket, konfliktusokat gerjeszt a nem romák és a romák, illetve a tősgyökeresnek tekintett és az újonnan érkezett romák között. A tapasztalatok szerint ugyanis a beköltözők nemcsak szegények, de szokásaik, viselkedésük elüt a helyben elfogadott normáktól, szokásoktól, s az újonnan érkezettek csak igen gyengén képesek integrálódni a helyi társadalomba. A szociális okokból fakadó migráció egy-egy település határain belül is elindulhat. Ez látható például Nagykőrösön, ahol a külterület funkcióváltása - a hajdan a gazdálkodás színtereként szolgáló külterületi ingatlanok lakáscélú hasznosítása - a szegények különböző csoportjainak a belterületről való kiszorulásával jár. A düledező, romos tanyákba a legnagyobb szegénységben élő városi roma családok költöznek, míg a közelebbi, zártkerti, toldozott-foldozott „kalyibák” a belterületről kihúzódó nem roma szegény családok számára kínálnak lakhatást.

Magyarországon a szegények többsége nem roma (Ferge, Tausz, Darvas 2002), de a romák aránya növekszik a szegény népességen belül, s az egyre szegényebb rétegek felé haladva mind nagyobb arányban vannak jelen (Bass, Darvas, Dögei, 
Ferge, Tausz 2007). Kutatásunk során interjúpartnereink a szegénység etnikus természetét firtató kérdésre válaszolva hangsúlyozták, hogy a szegénység nem tekinthető kizárólag roma problémának, nem csak a romákat sújtja, nem romák („magyarok”) éppen úgy szegénységben élnek, mint a romák. Amikor azonban a szegénységből fakadó anyagi, egészségügyi, lakhatási, életviteli stb. problémák gyakoriságáról, sürűsödéséről, a szegénység újratermelődéséről beszéltek, kiderült, hogy a legsúlyosabb helyzetben a gettósodó vagy magas roma aránnyal jellemezhető települések, településrészek vannak, s hogy a mélyszegénységben élők körében nagyobb számban találhatunk romákat. A mélyszegénység nem csak ott van jelen, ahol romák élnek. A szegénységről szóló elbeszélésekben mindazonáltal tetten érhető az a szemlélet, amely a romák szegénységéhez és a roma szegénységhez nem pusztán a nincstelenséget, szükölködést, nélkülözést, hanem az érintettek önmagukkal és környezetükkel szembeni igénytelenségét, a nemtörődömséget, felelőtlenséget, dologtalanságot stb. is kapcsolja. Egy, csak nem romák lakta falu polgármestere tömören a „cigányabbak a cigányoknál" fordulattal jellemezte a nem romák mélyszegénységben élo és „megélhetési segélyeseknek” nevezett csoportját. Nem a szóban forgó település az egyetlen, ahol élet- és lakáskörülményeik, viselkedésük, munkához való viszonyuk, szorgalmuk alapján és nem egyszer etnikai törésvonal mentén többé-kevésbé éles megkülönböztetést tesznek az „érdemtelen” (követelőző, igénytelen, lusta, a gyerekei taníttatásával nem törődo, ...) és „érdemes”, tisztes (dolgos, igyekvő, a környezetét rendben tartó, gyerekeit tanulásra ösztönző, ...) szegények között.

Az érdemtelen és érdemes szegények megkülönböztetése körül szövődő diskurzus felerősödése egyfelől a szegénység mélyüléséből, másfelől az elszegényedésből, a korábban biztosnak látszó egzisztenciák megrendüléséből fakad. Terepeinken diplomás munkanélküliségről és széles körű eladósodottságról egyaránt hallottunk. Ez a folyamat versenyt indíthat el a helyi erőforrásokért, munkalehetőségekért, támogatásokért a romák és nem romák között, ugyanakkor az elszegényedéstől, lecsúszástól való félelem s az ebből fakadó frusztráció azon túl, hogy a kirekesztő diskurzusokat táplálja, gyengíti a szolidaritás szöveteit, a helyi társadalom integráló erejét (Feischmidt 2013; Simonyi 2010; Szalai 2013).

\section{Szegénység és projektvilág, helyi tapasztalatok}

A vizsgált települések túlnyomó többsége ${ }^{7}$ a kutatás ideje alatt vagy korábban részt vett és érintett egy vagy több olyan, elsősorban uniós finanszírozású projektben, amely a szegénység mérséklését szolgálja. ${ }^{8}$ E projektek tapasztalatait értékelve interjúpartnereink több problémát, hiányosságot említettek. Mivel a kutatás végső célja a megbízó elvárásának megfelelően az volt, hogy a következő tervezési ciklus számára hasznosítható, megfontolandó tapasztalatokat tár- 
junk fel és elemezzünk, kérdéseink a nehézségek, akadályok megismerésére irányultak, s e tanulmányban is ezek bemutatására törekszünk. Nem csupán praktikus megfontolásokból, hanem mert éppen így tudunk választ adni kutatásunk alapvető, a projektek eredményességére, hatékonyságára és fenntarthatóságára vonatkozó kérdésére.

A kutatás időszakában futó projekteket érintő technikai (vagy annak látszó) kérdéseinkre az önkormányzati, civil vezetők, szakemberek az egyik legfontosabb problémaként említették, hogy hosszú idő, néha több mint egy év telt el a projekt kidolgozása/benyújtása és a szerződéskötés között. Ez idő alatt, a kormányváltásból fakadóan, a projektek megvalósítását érintő átfogó, radikális változások történtek a közigazgatásban, közszolgáltatási intézményi struktúrában stb. Mindez elsősorban azért jelent problémát, mert a rendszer rugalmatlansága miatt nagyon nehézkes, ha éppen nem lehetetlen a pályázati tartalom legcsekélyebb módosítása is. E rugalmatlanság hátterében interjúpartnereink vélelmezték az irányító hatóság munkatársainak bizonytalanságát, ami eredhet a szakmai hátteret biztosító szervezetben (lásd az MTA Gyerekesély Programiroda megszüntetését, a gyermekszegénység felszámolását célul tűző program személyi, intézményi struktúrájának átalakítását) zajló változásokból, a munkatársak tapasztalatlanságából, a helyi projektmenedzsmentet segítő koordinátorok gyakori cseréjéből. A nagyobb volumenű projektek szakmai előkészítése, a leginkább rászorulók (projektnyelven a célcsoport) érdekeinek, igényeinek megjelenítése, a különböző szereplők közötti egyeztetés hosszabb időt igényel. A leghátrányosabb helyzetű (LHH) kistérségek programozásának ${ }^{9}$ kényszerüen szükre szabott tervezési szakasza (Kovács 2013) rossz emlékeket hagyott az érintettekben, egy-egy térségben arról is hallhattunk, hogy a programozás csak tovább rontott az amúgy sem harmonikus településközi együttmüködésen, s interjúpartnereink a megvalósítással sem voltak elégedettek, mert a térségek többségében végül jellemzően a nagy infrastrukturális fejlesztések és nem az egyenlőtlenségek, a szegénység mérséklését szolgáló projektek támogatására került sor. Ugyanakkor a kistérségi Gyerekesély programok előkészítését az abban résztvevo" szakemberek mintaszerünek tartották, mint mondták, ez volt szakmai pályafutásuk során a legalaposabban, legnagyobb körültekintéssel kidolgozott program.

A projekteket megvalósító önkormányzatok, szervezetek általában fontosnak tartják, hogy a közremüködő szakemberek helybeliek, a térségből származók legyenek, hogy lehetőség szerint a belső erőforrásokra támaszkodjanak. Éppen az egyébként rendkívül kedvezően értékelt Gyerekesély program kapcsán hallottuk azt az észrevételt, hogy a pályázati kiírás nem számolt a leghátrányosabb helyzetű térségek tényleges adottságaival, s nem tette lehetővé a megfelelő szakmai végzettséggel igen, de (munkahelyek híján) szakmai tapasztalattal nem rendelkező pályakezdő fiatalok alkalmazását, noha az ő foglalkoztatásuk, akár gyakornokként is, fontos szerepet játszhatna a képzett fiatalok helyben tartásában. Ahol pedig sikerül fiatalokat bevonni, ott gyakori probléma, hogy a projekteknek nincs 
folytatása, illetve hosszabb idő telik el a lezárás és az új projekt indítása között. Ilyen esetekben jellemző, hogy az újabb projektben már nem lehet a tapasztalatokkal rendelkező fiatal kollégákra építeni, mert a köztes időben másfelé keresnek munkalehetőséget. A kapacitásépítés pedig kezdődhet elölről. ${ }^{10}$

A fejlesztések léptékének kérdése alapvető probléma, főként azt követően, hogy a hazai - megyei, régiós - fejlesztési források eltűntek a rendszerből (lásd például Koós 2013; Váradi, Schwarcz 2013), a kisebb, de szükséges fejlesztésekre, pl. épületek, lakások felújítására nem állnak rendelkezésre források. ${ }^{11}$

Abból kiindulva, hogy alapvetően a következő tervezési/fejlesztési ciklusban is uniós pályázati források állnak majd rendelkezésre a (mély)szegénység kezelésére, mindenképpen szükség lenne kiszámítható pályázati rendszerre, ami egyszerre jelenti az egyes támogatási prioritások, kiírások folyamatosságát, illetve a projektek zárása és az újak indítása közötti időszak áthidalását lehetövé tevő támogatást. A folytonosság, kiszámíthatóság kérdésével függ össze az is, hogy a megkérdezettek hazai vagy uniós forrásból szükségesnek tartják az egyes településeken, szervezetekben a különböző projektek megvalósítása során kialakult szakmai, szakmaközi együttműködések folyamatos működtetését.

A szakmaközi együttműködések elért és remélt sikerei, valamint az egyes projektekben, legalább papíron megvalósított széles körü partnerség mellett is fennmaradni látszik az a régi, gyakran emlegetett probléma, hogy az egyes projektek, fejlesztések nem épülnek egymásra, szinergikus hatásukról beszélni nem lehet. Kétségtelen, hogy egyes településeken (pl. Katymár, Gyulaj), térségekben müködő szervezetek (pl. ZalA-KAR Térségi Innovációs Társulás) igyekeznek biztosítani saját projektjeik egymásra épülését, nem egyszer tetten érhető azonban a forrásszerzés kényszere, arról pedig jellemzően nem beszélhetünk, hogy a szervezetek, intézmények egyeztetnék projektelképzeléseiket és -tapasztalataikat, hogy elkerüljék a párhuzamosságokat.

A roma integrációt szolgáló uniós fejlesztések értékelését végző szakemberek megállapítása, hogy a „pályázati rendszer egyedi projektekre épülő szemlélete, illetve a romákat érintő koncentrált és összetett problémák kezeléséhez szükséges komplex és hosszú távú feladatok nem összeegyeztethetőek" (Teller 2012, 6.). Kutatási tapasztalataink aláhúzzák e megállapítás érvényességét a roma és nem roma szegénység kezelését szolgáló projektek esetében. A különböző projektek megvalósításában részt vevő szakemberek több esetben is megfogalmazták aggályaikat, egyiküket idézzük:

„Olyan félelmekkel teli az ember, hogy nem kampányszerü lesz-e ez megint.

Minden pályázatnak a veszélye ez, hogy valamit elkezdünk, tényleg felkorbácsoljuk a hullámokat, tényleg fellelkesülnek az emberek, hozzákezdenek dolgozni, és ott van, egy év után lezárjuk, és akkor mi van."

A hazai és uniós forrásból finanszírozott munkaerő-piaci, képzési, foglalkoztatási, a hátrányos helyzetű térségekben, szegénységben élő csoportok integrációját/befogadását szolgáló projektek egyik jellemző tulajdonsága a mind pontosabb célok ellenére is a "lefölözési elv" érvényesülése (lásd Messing 2013; 
Teller, Csite, Domokos, Forrai, Hajdu, Koltai, Kullmann, Prókai, Somogyi, Sőrés 2013). Mi is hallottunk arról, hogy a (relatíve) jobb helyzetű települések érdekei hogyan jelentek meg és érvényesültek a leghátrányosabb helyzetü kistérségek tervezése során, vagy arról, hogy a Gyerekesély, a TÁMOP 5.1.3. programokban a szolgáltatások a településvezetők elzárkózása vagy a programba bevonandók motiválatlansága, mobilizálásuk nehézségei miatt éppen a legszegényebb településeket és családokat érik el a legkevésbé, illetve hogy e körben a legnehezebb eredményeket felmutatni. Egy, a jelenlegi pályázati rendszert éles kritikával érintő alapítványi szakember szerint a pályázati rendszer kényszeríti rá a sikerorientált szemléletet a projektek megvalósítóira, akiknek teljesíteniük kell az indikátorokat, s ezért nem kockáztathatják a projektet. Véleménye szerint „a pályázati rendszer legnagyobb hibája, hogy bizonyos programokat le lehet úgy futtatni, hogy a társadalmi hasznosulásuk minimális legyen”. Más szakemberek arra hívták fel a figyelmet, hogy egy-egy jó programban is előfordul, hogy nehéz „elszámolni” az indikátorokkal, mert a projekt tervezésekor készült és az azt megalapozó szükségletfelmérés óta eltelt időben változások történtek, s mert az is előfordul, hogy az állami képzési, támogatott foglalkoztatási programok felszívják a célcsoporthoz tartozó embereket.

A szegénység mérséklését szolgáló programkonstrukciók egyre komplexebbé válnak, a mélyszegénységben élők problémáihoz és igényeihez közelítve többféle eszközt bevetnek a célok elérése érdekében (Kovács 2013). A TÁMOP 5.1.3. „Közösségi felzárkóztatás a mélyszegénységben élők integrációjáért” programot mindenütt - szkeptikus polgármesterek is - üdvözölték a közösség- és településfejlesztési elemek megjelenése miatt; mert sikerül érdekeltté, motiválttá tenni a szegény embereket helyzetük jobbra fordításában, s mert a helyi közösségekben talán meg lehet találni azokat az embereket, akik a program eredményeit majd fenntartják, továbbviszik. A fenntarthatóság kérdése azonban e program kapcsán kétféle módon is megfogalmazódik. Kétséges, hogy (projekt)források hiányában a szegény közösségek mégoly motivált tagjai képesek lesznek-e a projekt időszakában megszokott aktivitással, lelkesedéssel tovább dolgozni. Általában a TÁMOP-típusú projekteket illetően hangzott el több interjú során is, hogy e projektek ugyan sokat jelentenek aktuálisan az érintetteknek, „legalább érzik, hogy nincsenek egyedül, számithatnak valakire, aki foglalkozik velük", hogy erősíti méltóságérzetüket, önbecsülésüket, olyan képességekhez, tudáshoz juttatják őket, amelyek értékesek a mindennapi életvezetésben, képessé teszik őket a munkavállalásra. A munka- és megélhetési lehetőségek hiányán azonban a projektek nem képesek változtatni, ami kétségessé teszi hatékonyságukat.

„Fontos dolog a fölzárkóztatás, az oktatás meg a közösségfejlesztés, de nem ez oldja meg igazából a problémákat. Ha nem lesz munkahely továbbra se, nem lesz megélhetése a családoknak, akkor ezzel nem sokra megyünk. Lehet, hogy éppenséggel kombinálni kéne a kettöt [munkahelyteremtést és közösségfejlesztést]."

Nem tudhatjuk természetesen, hogy az elért emberi, közösségi változásokra miként és mikor lehet a jövőben építeni. Ezzel kapcsolatban hangzott el a megál- 
lapítás, hogy sajnálatos módon a hosszabb távú hatások, eredmények mérése nem épült be a rövid időtávban gondolkodó és működő pályázati rendszerbe.

Az 1999-ben létrehozott berettyóújfalui székhelyü Igazgyöngy Alapítvány a térségben hat intézményben folytat művészeti oktatást hátrányos helyzetü gyerekek számára, társadalmi kerekasztalt működtet és egy komplex modellprogramot visz a 350 lelkes gettótelepülésen, Toldon. A modellprogram többek között az önfenntartásra, a munka iránti motiváltság felkeltésére, munkahelyteremtésre (lásd ehhez Feldmár 2013) irányul, legfontosabb eszközei az egyéni, családi esetkezelés, a személyre szabott fejlesztés és a folyamatos jelenlét. Az alapítványi tevékenységek finanszírozási forrásai a normatív támogatástól az adományokig terjednek, a munkanélküli roma és nem roma asszonyok által készített kézműves termékek értékesítéséből befolyt bevételekből már ki lehet fizetni az önkéntesként dolgozó asszonyok természetben juttatott bérét. ${ }^{12}$ Amit müködésükben többek között figyelemre méltónak tartunk, az a hosszú időtávban való gondolkodás és tervezés, a folyamatos jelenlét, a szegényekkel való együttműködés, a problémákkal való szembenézés és a változtatásokra, a(z ön)korrekcióra való képesség. Az alapítvány mindig a működéséhez és a kezelendő/megoldandó problémákhoz illeszkedő kírásokra pályázik. Hosszú időbe, munkába telt, amíg kialakult egy aktív, dolgozó és felelősségteljes mag a mélyszegénységben élő, konfliktusoktól szabdalt roma társadalomban. Egyikük az alapítvány szerepéről így nyilatkozott: „mondjuk úgy, amióta itt van az Igazgyöngy, élhetöbb lett [a falu], de elötte nem volt, nem volt". Az alapítvány vezetője az általuk végzett munka elemeit másutt is adaptálhatónak tartja, hangsúlyozva, hogy a mélyszegénységből fakadó problémák megoldását egyszerre kell helyben (a speciális helyi adottságokhoz és igényekhez illeszkedően) és állami szinten megtalálni.

A szegénység mérséklését szolgáló projektek eredményességét, hatékonyságát érintő legérzékenyebb ponthoz értünk, éspedig a projektek és az intézményi struktúrák, tágabban a szegénységben élők helyzetét, perspektíváit messzemenően érintő közpolitikák viszonyához. A Gyerekesély program is szolgál e tekintetben tanulságokkal. A Sásdi kistérségben a 2013 végén lezárult program leghangsúlyosabb része az oktatási szolgáltatások minőségének javítása volt. Olyan kiegészítő szolgáltatásokról van szó, amelyek szükségesek a hátrányos helyzetű és halmozottan hátrányos helyzetü gyerekek iskolai sikerességéhez, amelyekre azonban a fenntartó önkormányzatoknak nem volt forrása. Legalábbis kétséges, hogy a projekt lejárta után az új állami fenntartó tud-e forrásokat nyújtani a szolgáltatások további biztosítására. Jelzésértékű, hogy a Gyerekesély program tervezése során a berettyóújfalui térségben csak az oktatási intézmények másfél milliárd forintos igénnyel jelentkeztek. Ezekben az esetekben a projektek a közszolgáltatások intézményi rendszeréből hiányzó források pótlására szolgálnak, ahogy beszélgetőpartnereink megfogalmazták: a TÁMOP projektjeinek egy része által nyújtott forrásoknak, szolgáltatásoknak az alapellátásban lenne a helye. Különböző értékelések, elemzések is rámutatnak e diszfunkcionális jelenségre. A nem infrastrukturális beruházást tartalmazó projekt 
„folyó finanszírozással müködtetett szolgáltatási közegbe ágyazódik, és csak abban az esetben érheti el a kívánt hatását, ha illeszkedik ahhoz, vagy képes magát az alapszolgáltatást megváltoztatni" (Zolnay 2010, 16-17.). A szerző hozzáfüzi, hogy az illeszkedés többnyire tökéletlen. Mások arra hívják fel a figyelmet, hogy a törekvések ellenére a különböző konstrukciók nem mindegyike tudja pótolni a romák integrációja szempontjából fontos alap- és szakellátások hiányosságait, s hogy „a fejlesztések eredményeinek fenntarthatósága a mainstream szolgáltatásokhoz való kapcsolódásuk hiányosságai miatt is bizonytalan" (Teller 2012, 7.).

Az interjúpartnereink többsége által fontos és hasznos szolgáltatásnak tekintett Biztos Kezdet Házak ${ }^{13}$ a projektidőszak lejárta után nem lennének fenntarthatók az állam támogatása nélkül. Darvas és Ferge (2013) szerint „amennyiben egy intézményről vagy elindított folyamatról kimutatható, hogy beleillik egy olyan állami fejlesztési koncepcióba, amelyhez szerezhetők költségvetési források, akkor sikerülhet elérni a normatív támogatást, és ebből fenntartható lesz az intézmény vagy szolgáltatás. A Biztos Kezdet gyerekházak esetében ez részben megtörtént." Más esetekben azonban úgy tűnik, hogy a mainstream szolgáltatások és a szegénység mérséklését szolgáló projektek, programok nem illeszkednek egymáshoz. Összességében egyetérthetünk azzal a véleménnyel, hogy

„az egész társadalmi problémát nem lehet projektekkel megoldani. (...) Az borzasztó, hogy van egy állami apparátus, ami (...) nem tudja a mélyszegénységben élők problémáit kezelni, és ezért uniós forrásokból átmeneti időszakokra próbálunk meg különböző szervezeti formákban olyan programokat, amik ezt segitik".

A szegénység, mélyszegénység újratermelődésének megakadályozásában az oktatási intézményrendszer kulcsszerepet játszik. Szóltunk már arról, hogy a forráshiány milyen módon befolyásolja a projektek tartalmát. A kutatásba bevont térségek, települések óvodáinak, iskoláinak egy részében az intézményvezetés és a pedagógusok egyaránt elkötelezettek az inkluzív pedagógiai módszerek alkalmazása mellett, s a különböző projektek által kínált lehetőségeket is a pedagógiai, nevelési szolgáltatások minőségi emelésének szolgálatába állítják. A projektek azonban nem helyettesithetnek, nem válthatnak ki egy hatékony, hosszú távú, a rendszer egészén átnyúló oktatási integrációs, a társadalmi befogadást szolgáló politikát, és annak a mindennapi pedagógiai gyakorlatokhoz, az iskolai mobilitási utakhoz rendelt állami forrásait. Ezt fogalmazta meg egy baranyai általános iskola igazgatója, amikor a roma gyerekek továbbtanulási esélyei kapcsán arról beszélt, mekkora a szakadék az általános és a középiskola között. Alig van néhány olyan középiskola, panaszolta, amelyik az integrált pedagógiai rendszer szemléletét követné, annak pedagógiai módszereit alkalmazná. A középiskolákban nincs tere a személyes fejlesztésnek, támogatásnak, amely ellensúlyozni tudná a családok továbbtanuláshoz kapcsolódó viszonyát, képes lenne kompenzálni a szegénységből fakadó hátrányokat.

„Miért gondolják azt, hogy egy család, aki nem tudta volna a gyerek középfokú oktatását sem finanszírozni - a Gandhi [Gimnázium] tette ezt meg he- 
lyette -, az majd a felsőoktatási tanulmányokat, ami még többe kerül, képes lesz finanszírozni? Nem képes, ez téves gondolat. Ha ezt a folyamatot nem viszik végig, és nem támogatják a halmozottan hátrányos helyzetü gyerekeket az általános iskola elkezdésétól a diploma megszerzéséig, akkor ez valahol megszakad. Az esetek többségében a nyolcadik osztály végén, de a Gandhinak köszönhetöen sok esetben az érettségi után. Azt gondolom, azzal mindenki tisztában van, hogy a cigányság felemelkedéséhez szükség van egy nagyszámú elitre. Egyetlen diákom van harminchárom éves pályafutásom alatt, aki diplomát szerzett. Sok olyan van, aki érettségit szerzett, de onnan már nem tudott tovább menni egy sem, pedig sok nagyon jó képességü diákom volt. A legfontosabb, hogy kell a példa a gyerekeknek, hogy a putriból egyetemre is el lehet jutni."

\section{Közfoglalkoztatás: a szegénység kezelésének közpolitikai eszköze}

A tanulmányunk bevezetőjében idézett Bertelsmann-jelentés egyik fontos tanulsága, hogy önmagában az anyagi jólétből nem következik a szegénység, kirekesztettség alacsonyabb foka. A szociális igazságosság - egy kulturálisan és történelmileg változó értékrendszer eredményeként kialakult - modern koncepciója szerint eme igazságosság megteremtése „nem annyira a kirekesztés kompenzálásán, mint a befogadásba történő befektetésen múlik", célja az egyénekben rejlő képességek egyenlő és szabad kibontakoztatásának biztosítása (Schraad-Tischler, Kroll 2014, 13.). Másként fogalmazva, a társadalmi igazságosság, a befogadó vagy összetartó társadalom megteremtése, elősegítése nagymértékben az államok közpolitikáin múlik. E tekintetben, ahogy erre több elemzés is felhívja a figyelmet, Magyarországnak súlyos deficittel kell szembenéznie.

A „szociálpolitika illetékességi területét érintő beavatkozások a közelmúltban inkább a kirekesztés irányába hatottak. E lépések közös vonása, hogy a döntések a szegények érdemességének legkülönfélébb módon végzett tesztelésein alapultak, és hogy teljes mértékben figyelmen kívül hagyták, semmibe vették az érintettek privát szféráját, integritását és az emberi méltósághoz való jogát." A szociálpolitikai reformjavaslatokat megfogalmazó független szakértők szerint a különböző kormányzati lépések „a hátrányos helyzetben lévők kriminalizálásához, végső kirekesztettségéhez és a társadalmon belüli kölcsönös félelmek, feszültségek és agressziók megnövekedéséhez vezet[nek]" (Darvas, Farkas, Győri, Kósa, Mózer, Zolnay 2013, 5.). Más kritikai elemzés szerint a jóléti, szociális rendszer átalakítását nem jellemzi koherens cél- és eszközrendszer, az egyes intézkedések hátterében neoliberális, neokonzervatív és etatista ideológiák keveredése figyelhető meg, ám egy politikai szándék mindenképpen azonosítható: a legkiszolgáltatottabb, legsebezhetőbb társadalmi csoportok védelmének teljes hiánya (Szikra 2014). 
A legfontosabb tapasztalat, amit interjúpartnereink megosztottak velünk, a szegénység mélyülése, a szegénységgel sújtott, elszegényedéssel fenyegetett emberek, családok körének bővülése. Túl a válság hatásain, munkahelyek megszűnésén, a megélhetés fokozódó nehézségein, e folyamat hátterében a 2007/2008-tól datálható „kirekesztő társadalompolitikai fordulatot” (Zolnay 2013, 18.) azonosíthatjuk, amely a szegény- és romaellenes diskurzusok erősödésével, a szociális ellátásokat munkateszthez kötő workfare felé tolódó ellátási rendszerrel, az ellátások feltételeinek szigorításával jellemezhető (Civil jelentés 2014; Ferge 2012; Zolnay 2013). E fordulat fontos, jelzésértékü eleme, hogy míg az Alkotmány rögzítette az állampolgárok jogát a szociális biztonsághoz, addig az Alaptörvény szerint az ország csupán törekszik arra, hogy szociális biztonságot nyújtson, $\mathrm{s}$ az állampolgárok már nem a „megélhetésükhöz szükséges”, hanem a „törvényben meghatározott" támogatásra tarthatnak igényt, s e támogatások mértékét „a közösség számára hasznos tevékenységéhez igazodóan” is meg lehet állapítani. Ez utóbbi módosítás a segélyek közmunkához kötése előtt nyitotta meg az utat (Vida 2013, 25-26.; lásd még Szikra 2014). A szociális biztonsághoz való jog alkotmányos szűkítése mellett aprónak tűnő változás, hogy a „társadalmi befogadás/inklúzió" az utóbbi években kikopott a (szak)politikai szótárból, helyét a „társadalmi felzárkóztatás” foglalta el (Vida 2013). A Nemzeti Felzárkóztatási Stratégia ${ }^{14}$ kitüntetett céljának tekinti a szegénységben és társadalmi kirekesztettségben élő, főleg roma népesség arányának csökkentését, a szegénység újratermelődésének megakadályozását, a javakhoz, szolgáltatásokhoz való egyenlő hozzáférés biztosítását, a társadalmi összetartozás erősítését, ám a konkrét kormányzati lépések szembemennek e törekvésekkel, kétségessé téve a közpolitikai dokumentumban megfogalmazott célok komolyságát (Civil jelentés 2014). A központosítás, a közoktatás államosítása, a tankötelezettség korhatárának lecsökkentése, a szociális segély ${ }^{15}$ és a közfoglalkoztatottak bérének csökkentése, a jogosultság feltételeinek szigorítása nem járulnak hozzá a szegénység és kirekesztettség, a társadalmi és területi egyenlőtlenségek mérsékléséhez, a társadalmi összetartozás erősítéséhez (lásd A munkaerőpiac peremén 2014; Civil jelentés 2014; Darvas, Farkas, Győri, Kósa, Mózer, Zolnay 2013; Nagy 2013; Nagy, Timár, Nagy, Velkey 2015; Szikra 2014).

Tanulmányunkban nem térhetünk ki e változások részletező bemutatására (lásd ehhez Civil jelentés 2014), ehelyett a közfoglalkoztatás új rendszerével, s azon belül a START program megvalósításával kapcsolatos kutatási tapasztalatainkról nyújtunk áttekintést. Ez a szűkítés két szempontból is indokolt. Egyfelől a kormányzat a munkanélküliség és a szegénység kezelésének jószerivel kizárólagos eszközévé tette a közfoglalkoztatást, másfelól a tartós munkanélküliséggel sújtott szegény családok túlnyomó többsége a legális munkaerőpiachoz döntően vagy kizárólag a közfoglalkoztatáson keresztül kapcsolódik.

A jelenlegi rendszer gyökerei az ezredfordulóra nyúlnak vissza, akkor tették a helyi önkormányzatok számára kötelező feladattá a közcélú munka szervezését, $\mathrm{s}$ az ebben való részvételt a szociális segélyre való jogosultság felté- 
teleként rögzítették. Közvetlen előzményének és alapjának az Út a munkához program tekinthető, amely átalakította a szociális segélyezés rendszerét és szigorított a jogosultság feltételein (Csoba 2010). Kutatások sora bizonyítja, hogy a közfoglalkoztatás nem javítja a résztvevők foglalkoztatási esélyeit, nem tölti be az elvárásként megfogalmazott munkaerő-piaci (re)integrációs célját (a teljesség igénye nélkül: lásd az Esély 2010/1-es különszámának tanulmányait, valamint Fazekas, Scharle 2012; Köllő, Scharle 2011). Az is igazolható, hogy léteznek olyan aktiváló foglalkoztatáspolitikai eszközök, amelyek a közfoglalkoztatásnál eredményesebben segítik az elsődleges munkaerőpiacra való belépést (lásd A munkaerőpiac peremén 2014; Csoba, Nagy 2011). E tapasztalatok ellenére a kormányzat a munkanélküliség és a szegénység problémáját a közfoglalkoztatás kiterjesztésével kívánja megoldani, amely egyszerre tölt be szociális, foglalkoztatási és politikai funkciót. Vagyis a munkanélküliek számára a segélynél magasabb összeget biztosít; segít abban, hogy megőrizzék a munkaképességüket, visszajussanak az elsődleges munkaerőpiacra, hozzájárul a feketemunka visszaszorításához; pótolja a korábban elvont önkormányzati forrásokat és tompítja a helyi társadalmi feszültségeket. ${ }^{16}$ Mások és a magunk kutatási tapasztalatai szerint e hármas célkitűzések megvalósítása nem sikerült teljes mértékben (Messing 2012; Scharle 2011).

Az érintett településeken, hátrányos helyzetü kisvárosokban, mindenekelőtt azonban a falvakban a START közmunkaprogram köré szerveződik a mindennapi élet. „Az utóbbi évek legjobb programja ez a START közmunkaprogram. Sajnos, hogy más lehetőség nincs itt alapból, de hát ezzel kell élnünk, ami gyakorlatilag van." Az idézett polgármester nem áll egyedül a véleményével; interjúpartnereink túlnyomó többsége a nyilvánvaló problémák és ellentmondások ellenére üdvözölte a programot, azért, mert abból indulnak ki, hogy a településeiken, a környékükön egyáltalán nem, vagy csak kevesek számára elérhetően léteznek munkahelyek, illetve hogy a tartósan munkanélküli, képzetlen, megkopott munkavégző képességü emberek számára más lehetőség nem adódik, el sem képzelhető. Széles körü egyetértés mutatkozik tehát abban, hogy az önkormányzatoknak tartósan be kell rendezkednie a közfoglalkoztatásra. Hozzá kell ehhez tennünk, hogy a jelenlegi gyakorlattal szemben kritikus szakemberek sem utasítják el feltétlenül és teljes egészében a közfoglalkoztatást, de csupán egy és nem kizárólagos, univerzális foglalkoztatáspolitikai eszköznek tekintik. ${ }^{17}$ Arra pedig, hogy a szociális szakma és az érintettek is tartósan számolnak a közfoglalkoztatással, nem csupán a Közmunkások Szakszervezete, hanem a Magyar Szegénységellenes Hálózat segítségével megalakult, egyelőre a fővárosban működő Közmunkás Mozgalom a Jövőért is felhívja a figyelmet.

A START lelkes fogadtatása részben valóban a forrásvisszapótlásnak köszönhető; az Út a munkához program idején a településvezetők sérelmezték, hogy nincsenek források az eszközbeszerzésre, ma nem egy polgármesteri hivatal udvarán látni jó állapotban lévő traktorokat, a programban részt vevő települések 2011 óta jelentős mezőgazdasági és az egyéb ellátott feladatokhoz szükséges 
gépparkot hoztak létre. A korábbi programokat érintő kritikákban gyakran megfogalmazott problémára, az értékteremtö munka hiányára is választ adott a START, éspedig a mezőgazdasági alprogram révén. ${ }^{18} \mathrm{Az}$ Út a munkához program arra ösztönözte az önkormányzatokat, hogy minél több embert foglalkoztassanak a közmunka keretében. Ezzel szemben a START program sokak által üdvözölt hozadéka, hogy a korábbiaknál nagyobb mértékben nyújt lehetőséget arra, hogy az arra érdemesnek tartott munkanélküliek számára hosszabb időtartamra (10-12 hónapra) biztosítson nyolcórás foglalkoztatási lehetőséget s így kiszámítható jövedelmet. „Csak azok vannak beválasztva a START-ba, akik tudják, mi az, hogy munkahely, vagy felérik ésszel, és el lehet nekik magyarázni." Nem mindenki fogalmaz ilyen sarkosan, de az önkormányzati vezetők többsége hangsúlyozta, hogy a munkához való hozzáállás, szakértelem, megbízhatóság szempontjai mentén válogatják ki a közmunkásokat. Ez azt is jelenti, hogy a rosszabb, alacsonyabb presztízsű, illetve rövidebb ideig tartó munkák jutnak azoknak, akik az önkormányzatok szerint nem alkalmasak rendes munkavégzésre, akik a legelesettebbek, a legtöbb problémával küszködnek, akiket csak nagy nehézségek és segítség árán lehet(ne) a munka világába be- vagy visszavezetni. Van, ahol ők a "harmincasok”, vagyis azok, akiknek 30 napra ajánl az önkormányzat „önkéntes” munkát, ami szemétszedést jelent, ott úgymond nem tudnak kárt okozni. A Zalaszentgróti kistérségben évek óta rendszeres kistérségi közmunkaprogramok értékelése kapcsán egyik beszélgetőpartnerünk így fogalmazott: „Mi azokkal tudunk foglalkozni, akik még nem csúsztak le teljesen, még meg tudnak kapaszkodni, hogy ne csússzanak tovább. És a többiekkel nincs, aki foglalkozna, se önkormányzat, se ellátórendszer." Úgy is fogalmazhatunk, hogy a közfoglalkoztatásban nem csupán érvényesül, de a START program kiemelt támogatása révén intézményesült a "lefölözés" elve, a jó, megbízható, szakmával rendelkező közmunkások rendszerben tartása önkormányzati érdek (Koltai, Kulinyi 2013), ami ugyanakkor be is zárja ezeket az embereket a közfoglalkoztatásba.

Van azonban néhány olyan település is, ahol lehetőség szerint minden jogosultat beforgatnak a közfoglalkoztatás rendszerébe, hogy ha rövid ideig is, de munkához és a segélynél magasabb jövedelemhez jussanak. Aprófalvakban, illetve olyan településeken találkoztunk ezzel a gyakorlattal, ahol még alkalmi munkára sincs lehetőség. Nagyobb létszámú ember közfoglalkoztatásba való bevonására azokban a falvakban láttunk példát, ahol már korábban is folyt „értékteremtő" mezőgazdasági munka, jellemzően szociális földprogram keretében, illetve ahol a községvezetés az önellátó, gazdálkodó falu megteremtésére törekszik (kutatási terepeink között ilyen pl. Belecska, Katymár, Kisvejke, Túristvándi, Rozsály). A kisebb településeken, aprófalvakban, ahol hiányoznak vagy esetlegesek az önkormányzati szervezésű mezőgazdasági termelés előzményei, jellemző, hogy a rászorultaknál kevesebb munkanélkülit tudnak bevonni a közfoglalkoztatásba, s nem, vagy nemcsak azért, mert nincs elég alkalmas ember, hanem a feladatok, földterület és a források szükössége miatt is. Hiába szeretnének, nem tudnak mindenkinek közmunkát, illetve értelmes feladatot biztosí- 
tani. Ezekben az esetekben a kimaradók számára az önkéntes munka lehetősége kínálkozik. Néhány önkormányzat/körjegyzőség magára vállalta, hogy a munkaügyi kirendeltségtől megkért listák alapján értesíti az érintetteket, hogy jelentkezzenek önkéntes munkára, nehogy elveszítsék jogosultságukat a szociális segélyre (foglalkoztatást helyettesítő támogatásra). Ám az önkormányzatok másik része ezt nem tekinti feladatának, ahogy előfordul, hogy az önkéntes munka alkalmazásáról is lemondanak. Arra is találtunk példát, hogy civil szervezetek gondoskodtak arról, hogy az érintettek elvégezhessék a harminc nap önkéntes munkát, akár TÁMOP-os projekt keretében (Bonyhád és térsége, Kisvaszar a sásdi térségben), akár az adott szervezet mindennapi müködésébe illeszkedve (Told). ${ }^{19}$

A megkérdezett településvezetők, szociális szakemberek, közfoglalkoztatás-szervezők körében konszenzus mutatkozott abban, hogy a (köz)munka jobb, mint a teljes kiszorulás a munka világából, hogy a munkával szerzett jövedelem nemcsak magasabb a segélynél, de értékesebb is. A közfoglalkoztatáshoz füzött elvárások, illetve a vele kapcsolatban felsorolt eredmények között különböző megfogalmazásokban, első helyen szerepel a munkára, rendszerességre való (vissza)szoktatás, néha „a segélyekről való leszoktatás”. Mindez egybevág a közfoglalkoztatást szervezők körében végzett empirikus kutatás eredményeivel; a megkérdezettek a program legfontosabb hozadékai között említették a munkatesztet, vagyis azt, hogy kiszüri azokat a munkanélkülieket, akik dolgozni akarnak, és hogy csökkenti a segélyezettek számát (Koltai, Kulinyi 2013). A hivatkozott kutatás tapasztalatai szerint a közfoglalkoztatás legfontosabb értékének a gazdasági hasznot tekintik, amennyiben költségkímélő munkaerőt bocsát az önkormányzatok és intézményeik rendelkezésére. Egyre terjedő, az ombudsman szerint „rendszerszerü hiba” ${ }^{20}$ az a gyakorlat, hogy az önkormányzati alkalmazásban álló munkatársakat elbocsájtják, hogy aztán közfoglalkoztatottként, alacsonyabb bérért végezzék el ugyanazt a munkát. Van olyan kisváros, ahol a takarékoskodást szem előtt tartva a városgondnokság munkatársait már évek óta közmunkásként foglalkoztatják. Nagyobb településeken iskolai konyhák kisegítőiként, önkormányzati intézmények takarítóiként jellemzően már hosszú évek óta csak közmunkásokat alkalmaztak, s beszéltünk olyan kisvárosi polgármesterrel, aki nehezményezi, hogy a START miatt a közfoglalkoztatás e hagyományos formája jószerivel teljesen eltűnt. Nem marad hát más, mint a „trükközés”; aki papíron a START keretében kint kapál a kukoricaföldön, az gyakorlatilag a konyhán pucolja a zöldséget, vagy végzi korábbi irodai munkáját.

A START közmunkaprogram leghangsúlyosabb eleme a mezőgazdasági mintaprogram, amelyhez ha nem is OKJ-s, de tanúsítványt adó szakmai képzés kapcsolódik, s amely értékteremtő jellegében is különbözik a program többi, a közfoglalkoztatás hagyományos tevékenységi területeihez (közutak, árkok, közterületek rendben tartása) kapcsolódó elemétől. E programelemmel kapcsolatban több kétely is megfogalmazódik. Más kutatási tapasztalatokkal egybehangzóan (Koltai, Kulinyi 2013), interjúpartnereinktől általános kritikaként 
hallhattuk, hogy nem átlátható és nem is kiszámitható a program tervezése és bonyolítása, sok az esetlegesség, a feltételek, a támogatott tevékenységek, a foglalkoztatható emberek száma évente változik, nem gördülékeny a kommunikáció a minisztériummal, a program rendkívül nagy adminisztratív terhet ró az önkormányzati apparátusokra. Túl ezen, mindenekelőtt nyilvánvaló, hogy a polgármesterek többsége nem ért a mezőgazdasághoz, kénytelen botcsinálta agronómussá, „téeszelnökké” válni. Főként aprófalvakban, kistelepüléseken ők ülnek a traktorra - ha van hozzá jogosítványuk, ha nincs -, ők tartják a munkavédelmi eligazítást, ha kell, beállnak kapálni, megfelelő tároló helyiség híján a saját udvarukon tartják a gépeket és maguk is javítják, hogy ezzel is takarékoskodjanak a falunak, mert a támogatásból nem futja mindenre.

A programban megtermelt árukat (a legkülönfélébb zöldségek, eper, kukorica, ritkábban gyógynövény) a települések értékesítik, jellemzőn piaci áron alul a helyi, környékbeli közétkeztetést biztosító konyhák, ritkábban vendéglők, valamint a helyi lakosok számára. Néhány példát a szabad piaci értékesítésről is hallottunk, jellemzőbb azonban a helyi felhasználás. Falvak sora gondolkodik a megtermelt áruk feldolgozásáról, tésztaüzem, savanyító-tartósító üzem létesítését tervezik. Kétségtelen, hogy a START mezőgazdasági közmunkaprogram az értékképzésen túl megtakarítási lehetőséget jelent a települések számára, a helyi konyhák, családok a piaci árnál olcsóbban jutnak termékekhez, amelyek értékesítéséből az önkormányzati kasszába is folyik egy kis bevétel, igaz, azt gyakran az előző évben keletkezett veszteségek pótlására kell visszaforgatniuk. A közfoglalkoztatás keretében termelt áru értékesítése azonban piactorzitó hatással jár, mert állami támogatással előállított termékekkel lépnek a piacra, ahonnan - ahogy erről nem egy példát hallottunk - kiszoríthatják a mezőgazdasági kistermelőket, s veszteséget okozhatnak a helyi kisboltok üzemeltetőinek.

Az egyik zalai kisfaluban a huszonegy közmunkás közül négyen vesznek részt a mezőgazdasági programban, ami itt gombatermesztést, valamint a közösségi kertben szántóföldi zöldségtermesztést jelent. A helyi értékesítés mellett 2012-ben rendkívüli segélyként 140 család kapott gombát, krumplit, paradicsomot. A polgármester kiszámolta, hogy 2012-ben egy kilogramm paradicsom előállítási ára 800 forint volt. A program állami finanszírozás nélkül nem működne, piaci szempontból nem tud elöállítani versenyképes terméket. Ugyanígy, a piaci szempontokat mérlegelte az egyik Tolna megyei polgármester: „nekem a kezdetektől kezdve ez volt az egyetlen problémám (...) ha mindenki elkezd krumplit termelni, akkor megfojtjuk saját magunkat". A szóban forgó polgármester kezdeményezte, hogy a térség települései a helyi adottságoknak, hagyományoknak megfelelően hangolják össze a termelésüket, s szívesen látta volna, ha a termények felvásárlását, feldolgozását egy térségi szintű üzem végzi. Törekvéseit egyelőre nem koronázta siker. Jellemzo, hogy a polgármesterek a saját településükben gondolkodnak a közfoglalkoztatás vonatkozásában is; helyi termékek helyi piacában. Ám még ott is, ahol a falvak összefogtak, s közösen pályáztak a program megvalósítására, nehéz összehangolni a termelést és az 
értékesítést. A szóban forgó településeken nekiálltak tartósítani a megmaradt és értékesíthetetlen zöldséget, támogatási forrás, engedély, a munkaügyi szervezet, a minisztérium tudta nélkül; „ha tudnák, hogy savanyitunk, föbe lönének minket". Az egyik faluban annyi savanyú káposzta maradt készleten, hogy a szomszédos településeken is osztogatták karácsony előtt. Egy érintett község rendkívül kritikus polgármestere a START mezőgazdasági közmunkaprogramot a világ legdrágább segélyezési rendszerének nevezte.

„Nem tudom, ki találta ki azt, hogy ezt a mezögazdasági termelést akár a legjobb szándékú polgármester is úgy tudja végezni, hogy megérje. Kaptunk százmilliót, foglalkoztattunk körülbelül száz embert, és buktunk rajta önkormányzatokként másfél milliót. Hat hektárt müvelünk száz emberrel, miközben hat emberrel kéne száz hektárt. Ez irreális dolog."

A START közmunkaprogram kiszorító hatásáról más vonatkozásban is hallhattunk. Kutatási terepeink között van néhány modellprogramot működtető falu (Belecska, Kisvejke, Túristvándi, Rozsály), ahol majd’ két évtizede dolgoznak az önellátó, helyben megélhetési és boldogulási lehetőségeket kínáló falu kialakításán (Németh 2011). E programok fö pillérét a szociális földprogram jelentette (Jávor, Rácz 2013), azt tapasztalhattuk ugyanakkor, hogy az elmúlt három évben a START mezőgazdasági közmunkaprogram mintegy a szociális földprogram helyére lépett, és a helyi programok finanszírozásának jószerivel kizárólagos forrásává vált. Néhány jel e fejlemény veszélyeire és torzító hatásaira is utal. Egy szatmári faluban például 2013-ban a megszokottnál jóval kevesebb család kapcsolódott be a szociális földprogramba, miközben a START úgy száz falubeli számára biztosított közel egyéves foglalkoztatást. Az áprilistól késő őszig leterhelést jelentő uborkatermesztés és a közfoglalkoztatásban való részvétel összeegyeztethetetlen, így a rászoruló családok egy része inkább a kisebb kockázatot jelentő, huzamosabb ideig megélhetést biztosító közmunkát részesítette előnyben. A szatmári terepen azt is tapasztalhattuk, hogy a START által kínált támogatott foglalkoztatás felszívja a munkaeröpiac szezonális igényeit kielégito", jellemzően alacsonyan kvalifikált munkavállalókat. Az így keletkező hiányt a gazdák ukrajnai és romániai szezonmunkásokkal, illetve az élőmunkát kiváltó technológiai fejlesztésekkel, esetenként termékszerkezet-váltással (extenzifikálódás) pótolják, ami kiszoríthatja a hazai munkavállalókat a szezonális munkaerőpiacról, de legalábbis korlátozza vissza- és bekerülésük esélyeit. Egy baranyai agrárvállalkozó is arról számolt be, hogy a közmunka kiterjesztett rendszere miatt egyre nehezebb akárcsak feketemunkást is találni, a piacon elérhető keresetek alig magasabbak a közmunkás bérnél, s nem kell annyit teljesíteni, mint a piacon, ahol elküldik azt, aki nem megfelelően dolgozik. Ahogy igen sarkosan fogalmazott: „a társadalom számára visszatért a gulyáskommunizmus". Ugyan a településvezetők, közmunkaszervezők egy része igyekszik figyelembe venni a szezonális munkavégzés ritmusát, és például lehetőséget ad arra, hogy a közmunkások úgy vehessék ki a szabadságukat, hogy módjuk legyen eljárni, mondjuk bodzát, erdei gyümölcsöket szedni, a tapasztalatok azt mutatják, 
hogy a közfoglalkoztatás egyre inkább a nyilt munkaeröpiacon való boldogulás alternatívájává vált. Tudjuk, hogy a feketemunka is nagyobb esélyt kínál az elsődleges munkaerőpiacra való belépésre, mint a közmunka (Bass 2010), a közfoglalkoztatás jelenlegi rendszere azonban gyengíti a benne résztvevők kötődését a piaci alapon szerveződő munka világához.

A közfoglalkoztatásba bevont munkanélküli emberek szinte mindannyian örülnek a lehetőségnek, hiszen a szociális segélynél magasabb fizetést kapnak, a mezőgazdasági program résztvevőinek pedig akár három éven keresztül folyamatos munkát és fizetést is jelentett. Számukra a közmunka elsődleges értéke a többletjövedelem. Volt olyan önkormányzati beszélgetőpartnerünk, aki kifejezte reményét, hogy a közmunkások végre „rendes” munkahelynek tekintik az önkormányzati közfoglalkoztatás által kínált munkahelyet. Ugyanakkor többen is rámutattak arra, hogy e várakozás teljesülését sok tényező nehezíti. A 22800 forintos segélynél ugyan magasabb, de a „rendes” dolgozók minimálbérénél alacsonyabb fizetés nem tekinthető erős motiváló tényezőnek, ${ }^{21}$ a közmunka sokakat elkényelmesít, nem ösztönöz munkahelykeresésre, a „rendes” munkavégzés, a munkamorál, az öngondoskodás ellen hat, ${ }^{22}$ enyhíti a szegénységet, de biztosan nem jelent esélyt a szegénységből való kilábalásra (A közfoglalkoztatási csapda 2014; Koltai 2013; Koltai, Kulinyi 2013; Messing 2012). Ahogy korábban, ma sem tűnnek megalapozottnak azok a várakozások, hogy a közfoglalkoztatás lesz majd az elsődleges munkaerőpiacra be- vagy visszavezető út. „Átmeneti megoldás ez, kimenet nélkül.” Elenyésző azok száma, akik a közfoglalkoztatásból ki tudnak lépni a nyílt munkaerőpiacra, s ők jellemzően nem a tartós munkanélküliek közül kerülnek ki, a többség rendszeres visszatérő a közfoglalkoztatásban, s olyan fiatalok is vannak közöttük, akiknek más munkatapasztalata még nem volt (A közfoglalkoztatási csapda 2014; Koltai 2013; Koltai, Kulinyi 2013; Schwarcz 2014; Szikra 2014).

„Hosszú távon ez nem segítség! Addig, ameddig az állam finanszírozza a START munkát, vagy akármilyen közmunkát, addig per pillanat meg van oldva, biztos, hogy valami mutatók meg statisztikák jobban mutatnak, de ahogy az állam ezt nem fogja finanszírozni - ezek az emberek nem fognak sose szociális szövetkezetbe tömörülni! Esély nincs rá."

A jelenlegi közfoglalkoztatási rendszer fenntarthatóságának kulcsa a tartós állami finanszírozás; addig jelent „megoldást” a tartós munkanélküliség, a szegénység kezelésére, amíg az állam számára politikai prioritást jelent a közfoglalkoztatás rendszerének fenntartása, megszilárdítása. A munkanélküliek nagyobb része számára a közfoglalkoztatás jelenti a belátható horizontot, „,a közmunka elvesztésétől való félelem miatt a többség feladja a helyzetértelmezés igényét is, az önmaguk és gyerekeik jobb életére vonatkozó változtatás reményét is" (Civil jelentés 2014 , 14.). Erre világítanak rá egy olyan baranyai aprófalu polgármesterének szavai is, amelyben már tizenkét éve példaszerüen szervezik a közfoglalkoztatást. .„Ha valaki csak abban bizik, hogy jövőre is lesz közmunka, az nem tervez, nem néz elöre, innentól kezdve halott a dolog." A közmunkások többen érzik úgy, hogy 
munkájukat a helyi közösség hasznosnak tartja, megbecsüli, és kétségtelenül vannak törekvések a közmunkás lét „normalizálására”, a közmunkások közösséggé formálására: megtartják a közmunkások ünnepét, a polgármester együtt bográcsozik a közmunkásokkal (Koltai, Kulinyi 2013). Mindezek sem fedhetik el azonban, hogy a rendszer a függőségi viszonyokat erősíti a központi állam és a lokalitások, helyi önkormányzatok, helyben pedig személyes szálakon, a hatalom képviselöi és a közfoglalkoztatásra váró munkanélküliek, szegények között (Nagy, Timár, Nagy, Velkey 2015). A mégoly jóindulatú és segítőkész polgármesterek (és testületek) közmunkát elosztó, a mindennapi munkát irányító, a közmunkásokat fegyelmező szerepben jelentős hatalmat kapnak a szegény családok felett. Ez akkor is a rendszerből következő pozíció és szerep, ha e hatalommal nem élnek vissza, sőt, engedékenyek a „lazító” közmunkásokkal szemben is; „az egésznek nincs más célja, mint hogy megerősitse a polgármesterek hatalmát a szegények fölött."

\section{Összegzés}

Empirikus kutatási tapasztalataink arra hívják fel a figyelmet, hogy a szegénység, társadalmi kirekesztettség mérséklését szolgáló projektek eredményeinek fenntarthatóságát, hatékonyságát több tényező akadályozza. Az egymásra következő generációk életén átívelő, folyamatosan újratermelődő mélyszegénység olyan összetett problémaköteg, amelyet lehetetlen egy-egy rövid időtávú projekt keretében kezelni, megoldani. A mind pontosabb társadalmi és területi célzású, komplex beavatkozási eszközöket alkalmazó uniós projektek esetében is gyakran érvényesül a lefölözés elve, gyakorlata, aminek eredményeként éppen a legelesettebb, legreménytelenebb helyzetben élő szegény családokhoz nem érnek el a projektek szolgáltatásai. A legnagyobb dilemmát azonban az jelenti, hogy a szegénység mérséklését szolgáló projektek célkitűzése, szemlélete, eszközrendszere illeszkedik-e, s ha igen, miként a szegénység kezelésére (is) hivatott, a szegény családok életét közvetlenül vagy közvetve befolyásoló intézmények múködéséhez, tágabban a közpolitikákhoz.

Különböző elemzésekhez hasonlóan saját kutatási eredményeink is arra hívják fel a figyelmet, hogy az elmúlt években Magyarországon mélyült a szegénység, erősödött a kirekesztettség és a társadalmi, területi polarizáció. Noha nem hagyhatók figyelmen kívül a gazdasági válság hatásai, e folyamat hátterében azonosítható az a társadalompolitikai fordulat, amelyet a szociális biztonsághoz való jog alkotmányos szükítése, a szegény- és romaellenes diskurzusok erősödése, a szociális ellátásokat munkateszthez kötő workfare felé tolódó ellátási rendszer, az ellátások feltételeinek szigorítása jellemez. A fordulat ugyan nem előzmények nélküli, de minden korábbinál súlyosabban érinti a szegénységben élő családokat.

Tanulmányunkban a rendkívüli mértékben kiterjesztett közmunkaprogram helyi tapasztalatait mutattuk be. E program kétségtelen előnyökkel is jár, 
de kedvezőtlen hatásai sem elhanyagolhatóak. A közfoglalkoztatás jelenlegi rendszere két értelemben is piactorzító hatású. Egyrészt az állami támogatással eloállított termékekkel piacra lépő önkormányzatok kiszoríthatják onnan a mezőgazdaságból élő termelőket. Másrészt a közfoglalkoztatás a képzetlen, tartós munkanélküliek számára mindinkább alternatívaként jelenik meg az informális, fekete munkavégzésben való részvétellel szemben, s így gyengíti kötödésüket a piaci alapon szerveződő munka világához. A közfoglalkoztatás ma sem alkalmas eszköz arra, hogy a tartós munkanélkülieket be- vagy visszavezesse az elsődleges munkaerőpiacra. A közfoglalkoztatásban való részvétel a munkanélküliek számára hosszabb-rövidebb ideig magasabb jövedelmet biztosít a segélynél, s átmenetileg enyhítheti a szegénységüket, ám nem nyújt lehetőséget a szegénységből való kitörésre, és erősíti függésüket a helyi hatalomtól. A magyarországi társadalompolitikai fordulatról elmondható, hogy maga is hozzájárult a szegénység, a társadalmi polarizáció mélyüléséhez.

\section{Jegyzetek}

1 A társadalmi igazságosság (social justice) fogalma elválaszthatatlan a társadalmi kirekesztés és befogadás koncepciójától. A társadalmi igazságosság országonkénti indexének összehasonlítása hat dimenzió mentén történik, ezek: a szegénység megelözése, az oktatáshoz és a munkaerőpiachoz való hozzáférés, a társadalmi kohézió, az antidiszkrimináció, az egészség és a generációk közötti igazságosság. Az egyes dimenziók értékelése nem pusztán a statisztikai adatok, hanem az államok társadalmi igazságosságot, a szegénység és kirekesztés mérséklését elősegítő politikájának elemzésére is kiterjed (Schraad-Tischler, Kroll 2014).

2 Az EU szociális igazságosság index értékét tekintve Magyarország a 28 tagállam között a 25. helyet foglalja el (Schraad-Tischler, Kroll 2014, 8-9.).

3 A szegénység és kirekesztettség mérésére a következő indikátorok (ráták) szolgálnak: szegénységi kockázat, materiális depriváció, háztartási munkaintenzitás (munkaerő-piaci kirekesztettség), háztartássűrűség, háztartási kiadások, lakásdepriváció. Ezen indikátorokat a népsűrűség alapján vidékinek, illetve urbánusnak tekintett terekben hasonlították össze. A vidéki (ritka népsűrűségü) területeket, a háztartások munkaerőpiacról való kiszorulása és a lakásköltségek dimenziókkivételével jobban sújtja a szegénység és a kirekesztődés kockázata (Eurostat 2013, 226-235.).

4 „Az etnikus és nem etnikus szegénység mérséklését szolgáló szakpolitikai beavatkozások tapasztalatai vidéki térségekben" címü kutatás egyik szakaszában tizenegy vidéki terepen folytattunk empirikus vizsgálatot. A kutatási terepek kiválasztása során a korábbi lehatárolások mellett figyelembe vettük a szegénység mélységét és koncentrálódását, etnikus vagy nem etnikus jellegét, valamint a különböző uniós, hazai és egyéb forrásból támogatott projektek, programok jelenlétét, sűrűsödését. A terepek a problémák súlyának és a projektek, programok modellszerüségének megfelelően egész kistérségeket (a Berettyóújfalui, Encsi, Nagykőrösi, Sásdi és Zalaszentgróti járások települései), egymáshoz kapcsolódó településbokrokat (Kisvejke, Lengyel és Závod; Füged, Gyulaj, Nagyszokoly) fogtak át, illetve egy-egy településre (Belecska, Túristvándi és Rozsály, Katymár, Balkány) korlátozódtak. Az interjúkat készítette és az esettanulmányokat írta Farkas Zsombor, Fehér Kata, Hamar Anna, Magócs Krisztina, Rácz Katalin, Sain Mátyás, Schwarcz Gyöngyi, Váradi Monika Mária és Virág Tünde.

5 A szegénység nem homogén létállapot. Az idősek, gyermeket nevelő egyedülállók, fogyatékkal élők életkorhoz, családi és egészségi állapothoz kötődő szegénysége mellett találkozhatunk munkanélkülivé váló, elszegényedő családokkal, minimálbérért dolgozó szegényekkel, a válság, 
az eladósodás hatására bővülő jövedelmi szegénységgel, jelen van a területi, munkaerő-piaci és társadalmi hátrányok metszéspontjain sűrűsödő mélyszegénység, és ettől elválaszthatatlanul a gyermekszegénység. A szegénység jelenthet átmeneti, támogatással, a körülmények változásával eltűnő létállapotot, ám e jelenség mellett is tartósnak tűnnek azok a struktúrák, folyamatok, amelyek a szegénység újratermelődését eredményezik.

6 Az elsődleges munkaerőpiactól való távollét az a kardinális pont, ahol a szegénységről és a társadalmi kirekesztésről szóló diskurzus érintkezik egymással. A társadalmi kirekesztődés problémája akkor merült fel a nyugat-európai országokban, amikor nyilvánvalóvá vált, hogy véget ért a bérmunka társadalma, a magas szintű foglalkoztatás és az ezzel járó biztonság (Castel 1998, 2005).

7 A központi régióban elhelyezkedő Nagykőrösi járás települései nem tartoznak a kedvezményezett térségek közé. A jogosult települések között is van azonban olyan, amelynek vezetői nem vesznek részt a szegénység mérséklését szolgáló projektekben, programokban, mert nem tartják hasznosnak és/vagy nem rendelkeznek olyan kapacitásokkal, amelyek az ilyen típusú projektek megvalósítását lehetővé tennék.

8 A kutatás idején a leghátrányosabb helyzetű térségekben zajló legfontosabb programok: a mélyszegénység újratermelődésének megakadályozását célzó Gyerekesély és TÁMOP 5.1.3. „Közösségi fejlesztéssel a mélyszegénységben élők integrációjáért” program.

9 Az LHH Program célja a leghátrányosabb helyzetü 33 kistérség gazdasági és társadalmi felzárkóztatása volt. A programot komplexitás, ágazatközi megközelítés és programalapú megvalósítás jellemezte. (A program értékeléséhez lásd Kovács 2013.)

10 A szegénység kezelésére megoldásokat kereső települési önkormányzatok többsége megfelelő gyakorlatot, pályázói rutint szerzett a források megszerzéséért folytatott versenyben, a „későn ébredő" települések számára azonban komoly nehézséget okoz a támogatások elérését lehetővé tevő pályázatok megtervezése, előírásoknak megfelelő elkészítése, levezénylése, az adminisztratív és pénzügyi elvárásoknak megfelelő lezárása. Az erőforráshiányt gyakorta kívülről jött pályázatírók, projektmenedzserek „enyhítik”, amely ugyanakkor gátolja a belső humán (tervezői, szakmai megvalósítói, menedzsment) kapacitások kiépülését, a projektek helyi körülményekhez való adaptálását, továbbá nagymértékủ forrásvesztést eredményez. Mindez nem jelenti azt, hogy éppen a mélyszegénységbe süppedt, gettó- vagy gettósodó falvakban, településrészeken bármely változás elindításához ne lenne szükség a külső kapacitások, szakértelem és tudás bevonására. Az ilyen típusú projektek hosszabb távon többek között akkor tekinthetők eredményesnek, ha hozzájárulnak a helyi kapacitások megerősítéséhez.

11 Volt olyan polgármester, aki amellett érvelt, hogy szükség lenne egy olyan típusú (normatív) támogatásra, amely évente biztosít egy kisebb, szabad felhasználású összeget az önkormányzatok kis léptékủ fejlesztései számára.

12 A programok széles körben ismertek, az eredmények, fejlemények L. Ritók Nóra blogjában hétről hétre nyomon követhetők (http://nyomorszeleblog.hvg.hu). Kutatási terepeink között hasonló modellprogram indult Gyulajon, a Magyar Máltai Szeretetszolgálat Jelenlét-programja keretében. Lásd ehhez: „Az elgettósodott falvaink nem halnak ki”. Patyi Máté interjúja Németh Nándorral, a program koordinátorával, területfejlesztési szakemberrel. hvg.hu, 2013. december 25.

13 A Biztos Kezdet Házak integrált koragyermekkori fejlesztéseket biztosítanak hátrányos helyzetű településeken/településrészeken élő gyerekek és családjaik számára.

14 1430/2011. (XII.13.) kormányhatározat a Nemzeti Felzárkóztatási Stratégiáról, valamint végrehajtásának a 2012-2014. évekre szóló kormányzati intézkedési tervéről.

15 Az OECD országok körében Magyarország az egyetlen, amelyik a válságra az aktív korúak munkanélküli és szociális ellátásának nagymértékű, reálértékben több mint hatszoros csökkentésével reagált (A munkaerőpiac peremén 2014, 2.).

16 A közfoglalkoztatás nemzetközileg sem hatékony. Interjú Scharle Ágotával. http://www.portfolio.hu/gazdasag/a_kozfoglalkoztatas_nemzetkozileg_sem_hatekony_interju. 150711.html (Letöltés: 2014.október 4.)

17 A Budapest Esély Nonprofit Kft. és az Esély Labor Egyesület konzorciumában valósult meg az „Út a piaci munka világába” című, TÁMOP által támogatott kutatási projekt, amely nem csu- 
pán átfogó feltáró empirikus kutatást tartalmazott, hanem olyan módszertani kiadványok elóállítását is jelentette, amelyek egy hatékonyabb, méltányosabb, fenntarthatóbb közfoglalkoztatási rendszer kialakítását segítik elő. A jelentések és a kiadványok elérhetők a http://www.eselylabor.hu honlapon.

18 Fontos rögzítenünk, hogy természetesen korábban is voltak olyan önkormányzatok, amelyek törekedtek arra, hogy a közfoglalkoztatás keretében ne csupán hagyományos köztisztasági feladatokat lássanak el, hanem értékteremtő munkát is végezzenek a településen.

19 Az új közfoglalkoztatási rendszer bevezetése után született ombudsmani vizsgálat rámutatott a harminc napos közérdekü önkéntes munkavégzéssel kapcsolatban arra az érintettek szociális biztonsághoz való jogát veszélyeztető visszásságra, hogy az önkormányzatokat semmi nem kötelezi az önkéntes munka megszervezésére, és a hivatal munkatársainak vizsgálata arra is rámutatott, hogy az önkormányzatok e tekintetben nem is rendelkeznek megfelelő információkkal (Az alapvető jogok biztosának jelentése az AJB-4162/2012. számú ügyben. 2012. szeptember, 36.).

20 Az alapvető jogok biztosának jelentése az AJB-4162/2012. számú ügyben. 2012. szeptember, 15.

21 „Nem várható el magas szintű munkamotiváció a jelenlegi törvényi keretek mellett foglalkoztatott közmunkásoktól, a rendszeresen megszakított, nem kellő személyi és technikai infrastruktúrájú, erősen nyomott bérü és perspektíva nélküli munkaviszonyban" (Koltai, Kulinyi 2013, 60.).

22 Lásd ehhez pl. L. Ritók Nóra blogbejegyzését: Úton a munka alapú társadalom felé. Forrás: A nyomor széle 429. hvg.hu, 2014. augusztus 3.

\section{Irodalom}

A munkaerőpiac peremén lévő́k és a költségvetés (2014): Készítette: Bakó T., Cseres-Gergely Zs., Kálmán J., Molnár Gy. (kutatásvezető) és Szabó T. MTA KRTK Közgazdaságtudományi Intézet, Budapest

A közfoglalkoztatási csapda. A Magyar Szegénységellenes Hálózat jelentése a közfoglalkoztatottak hátteréról, helyzetéról és lehetőségeirool (2014): A jelentést összeállította: Farkas Zs., Molnár Gy., Molnár Zs., Magyar Szegénységellenes Hálózat Budapest

Andorka R., Spéder Zs. (1996): Szegénység Magyarországon 1992-1995, Esély, 4., 25-52.

Autonómia Alapítvány (2013): OSI Planning, Roma migráció. Budapest

Bass L. (2010):Az „Út a munkához” program hatása - egy kérdőíves felmérés tapasztalatai. Esély, 1.,46-64.

Bass L., Darvas Á., Dögei I., Ferge Zs., Tausz K. (2007): A szegénység és kirekesztés változása 2001-2006. MTA KTI Gyerekprogram Iroda, Budapest (Gyerekesély Füzetek; 3.)

Bihari Zs., Kovács K. (2004): Lejtők és csúszdák, avagy a foglalkoztatási esélyek térbeli egyenlőtlensége az ezredfordulón. In: A tudomány a gyakorlat szolgálatában. A foglalkoztatási szint bővitésének korlátai és lehetőségei. Magyar Tudományos Akadémia, Budapest, 7-35.

Castel, R. (1993): A nélkülözéstől a kivetettségig - a „kiilleszkedés” pokoljárása. Esély, 3., 3-23.

Castel, R. (1998): A szociális kérdés alakváltozásai. Max Weber Alapítvány, Wesley Zsuzsanna Alapítvány, Kávé Kiadó, Budapest

Castel, R. (2005): A társadalmi biztonság elvesztése. Mit jelent védetten élni? Esély, 4., 42-65, 5.,3-23, 6., 3-22.

Civil jelentés a gyerekesélyekról 2012-2013 (2014): Válogatta és szerkesztette Ferge Zs. és Darvas Á. Gyerekesély Közhasznú Egyesület, Budapest

Csoba J. (2010): A közfoglalkoztatás régi-új rendszere. Útközben az „Út a munkához” programban. Esély, 1., 4-24.

Csoba J., Nagy Z. É. (2011): A magyarországi képzési, bértámogatási és közfoglalkoztatási programok hatásvizsgálata. In: Fazekas K., Kézdi G. (szerk.): Munkaerő-piaci Tükör 2011. Budapest, MTA KTI, OFA, http://econ.core.hu/file/download/mt_2011_hu/egyben.pdf (Letöltés: 2014. szeptember 16.) 
Darvas Á., Ferge Zs. (2013): Gyerekesély programok kistérségi alkalmazása. A gyakorlat dilemmái és tanulságai. Gyerekesély Közhasznú Egyesület, Budapest

Darvas Á., Farkas Zs., Győri P., Kósa E., Mózer P., Zolnay J. (2013): A szociálpolitika egyes területeire vonatkozó szakpolitikai javaslatok. Esély, 6., 3-137.

Eurostat Regional Yearbook 2013 http://epp.eurostat.ec.europa.eu (Letöltés: 2014. szeptember 14.) http://doi.org/z2b

Fazekas K., Scharle Á. (2012): Munkaerőpiaci látlelet. In: Fazekas K., Scharle Á. (szerk.): Nyugdíj, segély, közmunka. A magyar foglalkoztatáspolitika két évtizede, 1990-2010. http://econ.core.hu/file/ download/20evfoglpol/kotet.pdf (Letöltés: 2014. szeptember 16.)

Feischmidt M. (2013): Hétköznapi nacionalizmus és a másság cigányként való megjelenése. In: Feischmidt M., Glózer R., Ilyés Z., Kasznár V. K., Zakariás I.: Nemzet a mindennapokban. Az újnacionalizmus populáris kultúrája. L'Harmattan, MTA Társadalomtudományi Kutatóközpont, Budapest, 401-447.

Feldmár N. (2013): Szociális innovációval a mélyszegénység ellen. In: Szuhay P. (szerk.): Távolodó világaink. A „cigány-magyar együttélés” változatai. Magyar Néprajzi Társaság, Budapest, 120-128. (Cigány Néprajzi Tanulmányok; 16.)

Ferge Zs. (2000): A társadalom pereme és az Európai Unió. In: Elszabaduló egyenlötlenségek. Hilscher Rezső Szociálpolitikai Egyesület, Budapest, 113-134.

Ferge Zs. (2012): A kormányzat lemondott a szegényekről. In: Vágányok és vakvágányok a társadalompolitikában. Válogatott tanulmányok. L'Harmattan, Könyvpont Kiadó, Budapest, 224-235.

Ferge Zs., Tausz K., Darvas Á. (2002): Küzdelem a szegénység és a társadalmi kirekesztés ellen. 1. kötet. Esettanulmány Magyarországról. Nemzetközi Munkaügyi Hivatal Közép- és Kelet-európai Iroda, Budapest

Gábos A., Szívós P., Tátrai A. (2013): Szegénység és társadalmi kirekesztettség Magyarországon 2000-2012. In: Szívós P., Tóth I. Gy. (szerk.): Egyenlootlenség és polarizálódás a magyar társadalomban. TÁRKI Monitor jelentések 2012. Budapest, 37-60.

Hamar A. (2010): Megújuló folytonosság. Közfoglalkoztatás egy észak-alföldi kistérségben. Esély, 1, 65-78.

Jávor K., Rácz K. (2013): Jó gyakorlatok a szociális földprogramban: a túristvándi és a belecskai példa. In: Kovács K., Váradi M. M. (szerk.): Hátrányban vidéken. Argumentum, Budapest, 156-170.

Koltai L. (2013): A közfoglalkoztatottak jellemzői. Esély Labor Egyesület, http://www.eselylabor.hu (Letöltés: 2014. október 15.)

Koltai L., Kulinyi M. (2013): A közfoglalkoztatást szervezők értékei. Esély, 5., 38-67.

Koós B. (2013): Három évtized a kistelepülések hazai finanszírozásában: a változó fejlődési lehetőségek kora 1980-2005. In: Kovács K., Váradi M. M. (szerk.): Hátrányban vidéken. Argumentum, Budapest, 275-295.

Koós B. (2015): A szegénység és depriváció a magyar település-állományban az ezredfordulót követően - avagy kísérlet a vidéki deprivációs index létrehozására. Tér és Társadalom, 1., 53-68. http://dx.doi.org/10.17649/TET.29.1.2681

Kotics J. (2013): „A mai napnak való vagyok...” Tartósan munkanélküliek megélhetési stratégiái. In: Nagy K. (szerk.): A szociális segély csökkentésének hatásai a vidéki Magyarországon, 2012 - interdiszciplináris dokumentáció. Pillangó Kutatás, Pro Cserehát Egyesület, Budapest, 50-69.

Kovács K. (2013): Területi, társadalmi hátrányok és beavatkozási politikák. In: Kovács K., Váradi M. M. (szerk.): Hátrányban vidéken. Argumentum, Budapest, 25-54.

Köllő J. (2006): A napi ingázás feltételei és a helyi munkanélküliség Magyarországon. MTA Közgazdaságtudományi Intézet, Budapesti Corvinus Egyetem Emberi Erőforrások Tanszék, Budapest

Köllő J., Scharle Á. (2011): A közcélú foglalkoztatás kibővülésének hatása a tartós munkanélküliségre. In: Fazekas K., Kézdi G. (szerk.): Munkaerö-piaci Tükör 2011, MTA KTI, OFA, Budapest, http://econ.core.hu/file/download/mt_2011_hu/egyben.pdf(Letöltés: 2014. szeptember 20.)

Krémer B. (2003): Uniós politikák és Nemzeti Akciótervek a szegénység és a társadalmi kirekesztettség elleni küzdelemre. Miniszterelnöki Hivatal Kormányzati Stratégiai Központ. (Stratégiai Füzetek; 15.)

Lukács Gy. (2013): „Mert enélkül itt elhitték volna, hogy nincs semmi” Munkaerő-piaci programok Dombosfalván. In: Szuhay P. (szerk.): Távolodó világaink. A „cigány-magyar együttélés” változatai. Magyar Néprajzi Társaság, Budapest,129-156. (Cigány Néprajzi Tanulmányok; 16.)

Messing, V. (2012): Kettévágott munkapiac, szétforgácsolt társadalom - Avagy hogyan dezintegrál- 
ják a magyar munkaerőpiacot és a társadalmat az állami foglalkoztatáspolitikai beavatkozások, különös tekintettel a közfoglalkoztatási programokra. In: Kovách I., Dupcsik Cs., P. Tóth T., Takács J. (szerk.): Társadalmi integráció a jelenkori Magyarországon, MTA Társadalomtudományi Kutatóközpont Szociológiai Intézet, Argumentum, Budapest, 204-220.

Messing, V. (2013): Active labour market policies with an impact potential on Roma employment in five countries of the EU. NEUJOBS Working Paper, 19.2, www.neujobs.eu/sites/default/ D19_2_final.pdf (Letöltés: 2014. augusztus 18.)

Nagy E., Timár J., Nagy G., Velkey G. (2015): The everyday practices of the reproduction of peripherality and marginality in Hungary In: Lang, T., Henn, S., Erlich, K., Sgibnev, W. (eds.): New geographies of Central and Eastern Europe. Palgrave-Macmillan, London

Nagy K. (szerk.) (2013): A szociális segély csökkentésének hatásai a vidéki Magyarországon, 2012 - interdiszciplináris dokumentáció. Pillangó Kutatás, Pro Cserehát Egyesület, Budapest

Németh N. (szerk.) (2011): A helyi kezdeményezésü gazdaságfejlesztési programok vizsgálata. Esettanulmányok. MTA Közgazdaságtudományi Intézet, Budapest

Scharle Á. (2011): A közcélú foglalkoztatás kibővülésének célzottsága, igénybevétele és hatása a tartós munkanélküliségre. Budapest Intézet, Budapest

Schraad-Tischler, D., Kroll, C. (2014): Social justice in the EU - A cross-national comparison. Social Inclusion Monitor Europe (SIM) - Index Report. Bertelsmann Stiftung http://www.bertelsmannstiftung.de/cps/rde/xbcr/SID-3D2360DC-BAA13673/bst/xcms_bst_dms_40361_40362_2.PDF (Letöltés: 2014. szeptember 16.)

Schwarcz Gy. (2014): Közfoglalkoztatás, agrártermelés és a társadalmi inklúzió. In Schiller K., TóthKirzsa F. (szerk.): Mwomboko. Köszöntő kötet Sárkány Mihály 70. születésnapjára. Makat, ELTE BTK Néprajzi Intézet, Budapest, 80-98.

Simonyi Á. (szerk.) (2010): Nyomorgó családok és szociális szolgáltatások. Szociálpolitikai és Munkaügyi Intézet, Budapest

Spéder Zs. (2000): A szegénység változó arcai. Tények és értelmezések. Andorka Rudolf Társadalomtudományi Társaság, Századvég, Budapest

Szalai J. (2002): A társadalmi kirekesztés egyes kérdései az ezredforduló Magyarországán. Szociológiai Szemle, 4., 34-50.

Szalai J. (2013): Hungary's bifurcated welfare state. Splitting social rights and the social exclusion of Roma. ASRF Working Papers, 5. http//www.gla.ac.uk/researchinstitutes/adamsmith/workingpapers/05 (Letöltés: 2014. január 10.)

Szikra, D. (2014): Democracy and welfare in hard times: The social policy of the Orbán government in Hungary between 2010 and 2014. Journal of European Social Policy, 5., 486-500. http://doi.org/zw7

Teller N. (2012): Roma integrációt szolgáló EU-s fejlesztések értékelése. Értékelési zárójelentés. Pannon Elemző Iroda, Hétfa Elemző Központ Kft., Városkutatás Kft., Budapest

Teller N., Csite A., Domokos V., Forrai E., Hajdu G., Koltai L., Kullmann Á., Prókai O., Somogyi E., Sőrés A. (2013): A társadalmi befogadást szolgáló fejlesztések (TÁMOP 5. prioritás) értékelése. Hétfa Kutatóintézet, Revita Alapítvány, Budapest

Váradi M. M. (2004): Zárványosodó munkaerő-piaci struktúrák és megélhetési stratégiák. In: A tudomány a gyakorlat szolgálatában. A foglalkoztatási szint bővitésének korlátai és lehetőségei. Magyar Tudományos Akadémia, Budapest, 36-54.

Váradi M. M., Schwarcz Gy. (2013): „Itt kis léptékekben kell gondolkodni”. In: Kovács K., Váradi M. M. (szerk.): Hátrányban vidéken. Argumentum, Budapest, 199-219.

Vida A. (2013): Esély vagy kényszer? Az aktív korú nem foglalkoztatottak jogosultságainak változásai a teljes jogú társadalmi tagság perspektivájából. PhD disszertáció. ELTE Társadalomtudományi Kar Szociológiai Doktori Iskola Szociálpolitikai Doktori Program, Budapest

Vida A., Virág T. (2010): Közmunka és napszám. Foglalkoztatás és szociális helyzet Dél-Békésben. Esély, 1., 100-118.

Vidra Zs. (2013): A szakképzetlen bérmunka szerepe falusi romák megélhetési stratégiáiban. In: Kovács K., Váradi M. M. (szerk.): Hátrányban vidéken. Argumentum, Budapest, 57-74.

Vidra, Zs., Virág, T. (2013): Some hypotheses and questions on the new wave of Hungarian Roma migration to and from Canada. In Vidra, Zs. (ed.): Roma migration to and from Canada: The Czech, Hungarian and Slovak Case. Center for Policy Studies, Central European University, Budapest 
http://cps.ceu.hu/sites/default/files/publications/cps-book-roma-migration-2013.pdf (Letöltés: 2014. január 11.)

Zolnay J. (2010): Fejlesztési támogatások hátrányos helyzetủ településeken. Zárótanulmány. In: Csongor A., Kóródi M. (szerk.): Fejlesztési támogatások hátrányos helyzetü településeken. MTA TK GYEP, Budapest (Gyerekesély Füzetek; 5.)

Zolnay J. (2013): Tartós munkapiaci kirekesztés, szegénység és társadalompolitikai válaszok - a kutatás kontextusa. In: Nagy K. (szerk.): A szociális segély csökkentésének hatásai a vidéki Magyarországon, 2012 - interdiszciplináris dokumentáció. Pillangó Kutatás, Pro Cserehát Egyesület, Budapest, 10-23. 